\title{
At håndtere flertydighed under pres - elevskriveres tekstnormer og skriverselv ved folkeskolens afgangseksamen i skriftlig fremstilling
}

\author{
Solveig Troelsen $\star$ \\ Syddansk Universitet og VIA University College
}

\begin{abstract}
Sammendrag
Når danske elever skriver tekster til afgangseksamen i skriftlig fremstilling, er formålet at skrive sig til censors og dermed uddannelsessystemets og samfundets anerkendelse. Situationen er presset, og forskning har vist at betingelserne er præget af flertydighed og kompliceres af dobbelte genreforventninger. I artiklen betragtes eksamensskrivning i et sociokulturelt perspektiv som en teksthandling i kontekst. Gennem såkaldt konstellationsanalyse af et udvalg af elevtekster undersøges eksamensskrivningen som svar på skriveordren og i forventning om censors bedømmelse, og elevernes tekstnormer og skriverselv ekspliciteres. Undersøgelsen finder en udpræget mangfoldighed og kompleksitet i tekstudvalget og identificerer fire forskellige elevtilgange til opgaven: strategisk kreativitet, umiddelbar narration, intuitiv iscenescttelse og kulturkompetent kommunikation. Sammenhængen mellem tekstmønstre og eksamenskarakter er relativt uklar. Dog ses en privilegering af de intuitive og umiddelbare tilgange, og personligt engagerende opgavetyper favoriseres karaktermæssigt. Multimodalt design og nøjagtig adressering af opgavens krav belønnes i begrænset omfang, mens verbaltekst i litterært inspireret stil anerkendes og delvist opvejer afvigelser fra eksplicitte krav. Fundene kalder på yderligere forskningsviden om og forskningsinformeret revision af den danske eksamenspraksis.
\end{abstract}

Nøgleord: Elevtekster; eksamensskrivning; danskfaget; skrivekonstellationer; dobbelt semiosfere

\begin{abstract}
Handling ambiguity under pressure: Student writers' text norms and 'writing selves' at the final examination in written composition

When Danish students take their final exams in written composition, their goal is to earn recognition from the external examiner and by extension the educational system and society. The situation is charged, and research has shown that the conditions can be ambiguous and complicated by double genre expectations. The article regards exam writing in a socio-cultural perspective as an act of writing within a given context. Through so-called constellation analysis of a selection of student texts, exam writing is studied as both a response to the writing prompt and in anticipation of the external examiner's assessment, and the students' text norms and 'writing selves' are explicated. The study finds a marked diversity and complexity in the selection of texts and identifies four
\end{abstract}

^Korrespondanse: Solveig Troelsen, epost: sotr@via.dk

(C) 2020 S. Troelsen. This is an Open Access article distributed under the terms of the Creative Commons Attribution 4.0 International License (https://creativecommons.org/licenses/by-nc/4.0/), allowing third parties to copy and redistribute the material in any medium or format and to remix, transform, and build upon the material for any purpose, even commercially, provided the original work is properly cited and states its license. 
different student approaches to the task: strategic creativity, immediate narration, intuitive staging and culturally competent communication. Correspondence between text patterns and examination grades is relatively obscure. However, a preference for the intuitive and immediate approaches can be seen, and personally engaging texts are rewarded with higher grades. Multi-modal design and accurately addressing the requirements of the writing prompt are rewarded to a limited extent, while verbal text and literary-inspired writing styles are acknowledged and partially offset deviations from the explicit requirements. The findings call for further research and for research-informed revision of Danish examination practices.

Keywords: Student texts; exam writing; Danish as a subject; writing constellations; double semiosphere

Responsible editor: Atle Skaftun

Received: August, 2019; Accepted: March, 2020; Published: June, 2020

\section{Indledning}

Afgangseksamen $i$ skriftlig fremstilling er den eneste nationale skriveprøve i dansk grundskole. ${ }^{1}$ Den gennemføres af alle elever og udgør én af danskfagets fire obligatoriske deleksamener. De øvrige er lasning, retskrivning og mundtlig dansk (STUK, 2016b). De fire delprøver skal bestås samlet med en gennemsnitskarakter på mindst $02^{2}$ for at give eleven retskrav på fortsat ungdomsuddannelse - dog har henholdsvis erhvervsskoler og gymnasiale uddannelser specifikke adgangskrav. Eksamen har altså high-stakes-værdi idet en succesfuld besvarelse kan bidrage til enten betydelig gevinst i form af adgang til samfundsmæssig anerkendelse og status gennem videreuddannelse eller tilsvarende tab når denne mulighed lukkes (Beck \& Jeffery, 2007). Dette er nyt i en dansk skolekontekst hvor der frem til 2015 var fri adgang til erhvervsuddannelser mens gymnasial ungdomsuddannelse indtil 2019 blot forudsatte grundskolens vurdering af eleven som egnet samt en gennemført afgangsprøve - uden karakterkrav. En anden ny praksis angår bedømmelsen som siden 2016 varetages alene af én beskikket censor der ikke som tidligere skal votere sammen med elevens lærer. Ordningen er efter to år evalueret

\footnotetext{
${ }^{1}$ Der er nationale test i læsning i 2., 4., 6. og 8. klasse, men ingen i skrivning.

${ }^{2}$ Den danske karakterskala er en 7-trinsskala som ækvivalerer ECTS-skalaen. Kravet for optagelse på en erhvervsuddannelse er et karaktergennemsnit på 02 eller mere i dansk og matematik, og prøven i skriftlig fremstilling vægter $25 \%$ i den samlede danskkarakter. Gymnasial ungdomsuddannelse forudsætter en gennemsnitskarakter for alle obligatoriske prøver på 5.
}

\begin{tabular}{|l|l|l|}
\hline $\begin{array}{l}\text { ECTS- } \\
\text { skala }\end{array}$ & $\begin{array}{l}\text { Dansk } \\
\text { skala }\end{array}$ & Beskrivelse \\
\hline A & 12 & $\begin{array}{l}\text { gives for den fremragende præstation, der demonstrerer udt } ø \text { mmende opfyldelse af fagets mål med ingen eller få } \\
\text { uvæentlige mangler. }\end{array}$ \\
\hline B & 10 & $\begin{array}{l}\text { gives for den fortrinlige præstation, der demonstrerer omfattende opfyldelse af fagets mål, med nogle mindre væsentlige } \\
\text { mangler. }\end{array}$ \\
\hline C & 7 & gives for den gode præstation, der demonstrerer opfyldelse af fagets mål, med en del mangler. \\
\hline D & 4 & $\begin{array}{l}\text { gives for den jævne præstation, der demonstrerer en mindre grad af opfyldelse af fagets măl, med adskillige væsentlige } \\
\text { mangler. }\end{array}$ \\
\hline E & 02 & gives for den tilstrækkelige præstation, der demonstrerer den minimalt acceptable grad af opfyldelse af fagets mål. \\
\hline FX & 00 & gives for den utilstrækkelige præstation, der ikke demonstrerer en acceptabel grad af opfyldelse af fagets mål. \\
\hline F & -3 & gives for den helt uacceptable præstation. \\
\hline
\end{tabular}




\section{S. Troelsen}

af en ministeriel følgegruppe som blandt andet konstaterer en meget lav bedømmerreliabilitet med en gennemsnitskorrelation på 0.55 svarende til $40 \%$ sandsynlighed for at to censorer giver samme karakter (Dolin, Nielsen, \& Rangvid, 2018, s. 17). Dermed føjes endnu et element af pres til elevernes situation idet den for dem afgørende bedømmelse må betragtes som særdeles usikker. Ydermere viser et studie af opgavemateriale og vurderingskriterier ved pågældende eksamen en flertydig instruktion i den skriveordre eleverne skal besvare (Troelsen, 2018), samt flertydige bedømmelseskriterier, og i den ny læreplan Fcelles mål for faget dansk fra 2015 (STUK, 2016a) optræder nye fagdiskurser side om side med gamle. Sammen med en ny prøveform (2017) med adgang til internettet placerer det prøven $\mathrm{i}$ et spændingsfelt mellem tradition(er) og nybrud. Tekstkulturen som eleverne skal skrive sig ind i, er således kompleks og relativt ustabil.

At skrive eksamenstekst er en situeret handling med et sammensat skriveformål der afføder dobbelte genreforventninger (fx Krogh \& Hobel, 2012; Togeby, 2015) og baserer sig på overvejende strategiske, men også kommunikative og rituelle elementer (Berge, 1988). Denne kompleksitet er konstitutiv for genren, men sjældent eksplicit kommunikeret i opgavematerialet (Troelsen, 2018, s. 163), og det indebærer store udfordringer for elevskriveren der foruden eksplicitte krav må adressere tavse forventninger og implicitte forudsætninger og rekontekstualisere skriveordrens fordringer om fx genre ind i eksamensskrivekulturen (ibid.). I denne artikel undersøges elevbesvarelser fra den danske afgangseksamen i skriftlig fremstilling i ovennævnte kontekst præget af på den ene side intensiverede krav og voksende betydning af eksamenskarakteren og på den anden tiltagende usikkerhed qua prøvekonstellationens flertydighed, faglige brydninger og lav reliabilitet. Undersøgelsen belyser gennem tekstanalyser elevernes normer for den gode eksamenstekst samt deres konstruktion af skriveridentitet (Ivanič, 2012). Elevbesvarelserne ses som tekstligt medierede handlinger i en high-stakes kultur- og situationskontekst. Formålet med undersøgelsen er at bidrage til en nuanceret forståelse af danske elevers eksamensskrivning til gavn for et praksisfelt i bevægelse og et forskningsfelt i sin vorden, ikke mindst hvad angår kvalitative dybdestudier. Artiklen søger svar på følgende forskningsspørgsmål: Hvad kendetegner elevbesvarelser ved afgangseksamen i skriftlig fremstilling 2017 som henholdsvis social handling, fagdiskurs og tekst fra globalt til lokalt niveau? Herunder: Hvilke tekstnormer kan udledes af elevteksterne? Og hvordan konstruerer eleverne sig selv som skrivere i tekstkulturen?

\section{Teoretisk ramme og metodologi}

\section{Eksamenstekster i kontekst - antropologisk tekstvidenskab}

Antropologisk tekstvidenskab ser teksten som "en semiotisk mediert henvendelse fra noen til noen om noe, med en hensikt i et spesielt øyeblikk i historien" (Berge, 2012, s. 85). Således affilierer den sig - som denne artikel - med dels en overordnet sociokulturel optik på eksamensskrivning (Skar, 2013, s. 32 ff.), dels et mere specifikt fokus på skrivning som literacy event som det kendes fra New Literacy Studies (Barton, 1998). NLS definerer sit genstandsfelt som "an activity, located in the space between thought 
and text" (Barton, s. 3). Her studeres dette gennem "observerbare skriftlige ytringer" (Krogh, 2015, s. 45), altså som handlinger realiseret i skriftlig form. Berge beskriver ytringer og tekster med afsæt i Bakhtins dialogisk kommunikative semiotik og forbeholder begrebet tekst til ytringer der er "kommunikativt og kulturelt relevante" og fungerer som "mulige indekser på kulturelt konstituerte tekstnormer" (Berge, 2012, s. 75). Disse tekstnormer knytter sig til dels (i dette tilfælde censors) læsning af tekst (receptionsnormer), dels skrivning af tekst (produktionsnormer) (Berge, 1996, pp. 31-32). I denne artikel fokuseres på elevers produktionsnormer for den gode eksamensbesvarelse. Tekstbegrebet i antropologisk tekstvidenskab er altså kulturkontekstuelt betinget, og erkendelsesinteressen retter sig mod at forstå tekster som "situasjonskontekstuelle ytringer i lyset av de mer eller mindre stabile kulturkontekstene de også er ytret i” (Berge, 2012, s. 80).

\section{Eksamensteksten som genre}

Er tekstnormerne i en kultur institutionaliserede, vil de udvikles til genrer (Berge, 2012, s. 81). Således betragtet er eksamensbesvarelse $i$ dansk skriftlig fremstilling en genre udviklet over tid og i interaktion med de kulturkontekster den historisk har udfoldet sig i, og kvalificerende for hvad der anerkendes som gyldige tekster. I dansk skolekultur har skriftlig fremstilling siden 1937 betegnet det at producere sammenhængende tekst og haft egen afgangsprøve siden 1958 (Indenrigsministeriet, 1941, 1958). Der er altså tale om en genre med en tekstkulturel historie udfoldet i dialog med 80 års danskdidaktiske diskurser. Termen genre tilskrives forskellig betydning indenfor forskellige domæner og diskurser hvilket er diskuteret nuanceret og omfattende af flere (fx Berge \& Ledin, 2001; Jordheim, 2008; Smedegaard, 2016), og anvendelsen forudsætter begrebsafklaring. I denne artikel bruges genre for det første som en linse jeg betragter teksthandlinger med. Her tages afsæt i Bakhtins pragmatiske og dialogiske begreb om talegenrer (Bakhtin, 1986) og nyretorikkens forståelse af genre som "a typified rhetorical response to (uptake of) a recurrent rhetorical situation" og som "social action" (Miller, 2015, s. 56). Dette genrebegreb er i tråd med det sociokulturelle udgangspunkt og anvendes fortrinsvis til at forstå eksamensbesvarelser som elevers sociale handlinger. For det andet anvendes genre og genrekrav visse steder kongruent med og i omtalen af den - ganske vist flertydige - betydning de tildeles i prøvemateriale og paratekster til afgangseksamen. Her dominerer en formalistisk og strukturel genreforståelse i både vurderingskriterier og skriveordre (Troelsen, 2018). At det er nødvendigt med et dobbelt genrebegreb, skyldes det Karlsson (med afsæt i Berge, 1996) beskriver som en dobbelt semiosfere med konkurrerende tekstnormer som skoletekster fungerer i (Karlsson, 1997, s. 174 f.). 40 års tiltagende fokus på i skolen at lade eleverne arbejde med genrer kendt fra andre kontekster har for de danske afgangsprøver medført en fremvækst af især varianter af journalistiske tekster. Det er imidlertid en pointe at disse altid er indlejret i skolens semiosfære. Dermed transformeres $\mathrm{x}$ avisoffentlighed til simuleret avisoffentlighed, omsluttet af og underordnet skolesemiosfæren.

Dette studies udvalg af elevtekster er eksempler på genren eksamensbesvarelse. De er alle anerkendt som kvalificerede ytringer i tekstkulturen eftersom alle har fået 


\section{S. Troelsen}

karakteren 02 eller mere af den bedømmende censor. Nogle tangerer grænsen for det antagelige og markerer således netop det sted hvor ytring bliver tekst, mens andre - i al deres forskellighed - typificerer den fuldt anerkendte tekst, og atter andre indtager en midterposition i tekstkulturens kvalitetskontinuum. De repræsenterer samtidig individuelle elevers tekstligt udfoldede "uptake of" den retoriske situation (jf. Millercitatet) og deres mere eller mindre omfattende internalisering af de institutionaliserede tekstkulturelle normer som tilgås intuitivt gennem deltagelse - enten man er elevskriver, censor eller forsker (Berge, 2012).

\section{Eksamenskonstellationen}

Skoleskrivningens retoriske exigence, den situation som kræver en skrivehandling som respons (Bitzer, 1968), indebærer oftest en skriveordre som initierer, rammesætter og inspirerer, og "elevteksten er (...) i grunden en social svarhandling på skriveordren" (Togeby, 2015, s. 274). Med afsæt i Bakhtins syn på ytringer og dermed tekster som fundamentalt dialogiske, dvs. svar på tidligere ytringer og indeholdende forventningen om svar (Bakhtin, 1986), har projektet Faglighed og skriftlighed (FoS) udviklet den såkaldte konstellationsmodel (Krogh, 2015) som indfanger skoleskrivningens sekventielle dialogicitet og desuden anlægger tre perspektiver på elevteksten som tekst, fagdiskurs og social handling (jævnfør også forskningsspørgsmålet). Modellen er siden tilpasset eksamenskonteksten i en undersøgelse af skriveordren ved afgangsprøven i skriftlig fremstilling (Troelsen, 2018, s. 147) og repræsenterer her eksamenskonstellationen idet den indfanger dels elevbesvarelsens udfoldelsesrum mellem skriveordrens initiering og det forventede svar i form af en karakter, dels den tredelte optik på teksten i kontekst:

\begin{tabular}{|l|l|l|l|}
\hline $\begin{array}{r}\text { Analyse- } \\
\text { perspektiv }\end{array}$ & Tekst & Fagdiskurs & Social handling \\
$\begin{array}{l}\text { Analyse- } \\
\text { enhed }\end{array}$ & & & \\
\hline Skriveordre & & & \\
\hline Elevtekst & & & \\
\hline Bedømmelse & & & \\
\hline
\end{tabular}

Figur 1. Konstellationsmodellen - tilpasset eksamenskonteksten.

I denne artikel analyseres elevteksterne først som social handling, derefter som tekst, eller mere præcist tekststruktur (se nedenfor), og som fagdiskurs. I FoS-projektets analyser af gymnasieelevers tekster manifesteres fagdiskurser især semantisk som fagtypiske vokabularer og kohæsionsmønstre (fx Hobel, 2011) der gradvist indoptages i elevteksterne og markerer tilegnelse af fag gennem erobring af fagsprog. Folkeskolens danskfag og navnlig den deri indlejrede forestilling om skriftlig fremstilling er ikke i samme grad forbundet med hvad man kunne kalde en substantivisk begrebsfaglighed. Den danskfaglige skrivnings vokabular er først og fremmest et metasprog og anvendes om, men ikke $i$ elevernes tekster. Eksempelvis er normen at man kender genren blog, 
men ikke anvender ordet i teksten. Fagdiskurs i eksamensbesvarelserne er således en diskursiveret faglighed forstået således at man ikke kan tale om reference til et fagligt indhold, men om diskursiv udfoldelse af skrivefaglighed. Elevteksterne benævner ikke viden, men udfolder eller performer denne diskursivt og kan tilsvarende diskursivt demonstrere fravær af viden. Dette gælder fra det globale til det lokale tekstniveau.

\section{Skriveridentitet}

Al skrivning, hævder FoS-projektet (Christensen, Elf, \& Krogh, 2014), er knyttet til identifikationsprocesser. Dette accentueres i eksamensskrivningen som i kraft af sin high-stakes-status foruden at evaluere elevens skrivekompetencer bidrager til enten at sikre eller fratage eleven muligheden for samfundsmæssig og personlig anerkendelse gennem videre uddannelse. Situationskonteksten er således ladet med livsdefinerende konsekvenser for den enkelte og i potenseret grad et spørgsmål om identitet i Gees forstand: "Being recognized as a certain "kind of person", in a given context, is what I mean here by "identity" (Gee, 2000, s. 99). Man kan sige at elevens udfordring i eksamenssituationen er at konstruere sig selv diskursivt på måder som anerkendes i tekstkulturen - at konstruere et anerkendelsesværdigt skriverselv (Ivanič, 1998, 2012). Ivanič anvender dette begreb omtrent synonymt med hvad hun skiftevis har omtalt som skriveridentitet og -identifikation, og det er adopteret af FoS-projektet. Selv anlægger hun fem perspektiver på begrebet hvoraf fire er relevante for dette studies analyser: Den sociokulturelle kontekst tilbyder elevskriverne (1) socialt tilgcengelige muligheder for selvhed som (2) det selvbiografiske selv affilierer sig med i sin konstruktion af (3) det diskursive selv som kan iagttages i den specifikke tekst. Desuden inddrages begrebet (4) self as author eller autorialt selv ${ }^{3}$ som refererer til skriverens selvfremstilling som forfatter.

\section{Metodologi - mellem bredde og dybde}

Det analytiske fokus rettes først og fremmest mod det niveau i tekstvidenskabens genstandsfelt der beskæftiger sig med tekster i en specifik tekstkultur (Berge, 2012, s. 86 f.). Det undersøges hvordan ytringer bliver til tekst - her hvordan elever skriver sig til anerkendelse i eksamenstekstkulturen - og hvordan tekster interagerer i dialog med tekstkulturelle kontekster. Dette operationaliseres i konstellationsmodellens trefacetterede perspektiv på elevbesvarelsen som tekst, fagdiskurs og social handling. Tekstmønstre studeres som tegn på kultur- og situationskontekstuel intentionalitet dels deskriptivt analytisk, dels i en abduktiv udledning af de normer som viser sig i mønstre og typiske træk. Der skelnes mellem teksters indre struktur og deres konfiguration (Berge, 2012, s. 82) forstået som afgrænsning i forhold til de kontekster de forholder sig dialogisk til. Tekstinterne strukturer er fx globale og lokale konnektionsmønstre og stilistiske karakteristika. Konfigurationen markeres blandt andet layoutmæssigt og ved såkaldte teksttcerskler (Togeby, 2015) og bidrager til at definere tekstens genreforhold i grænsefladen

\footnotetext{
${ }^{3}$ FoS-projektets oversættelse til "autoritativt selv" (Krogh, 2015) nedtoner forfatteraspektet som jeg finder vigtigt i den aktuelle fagdiskurs. Derfor denne oversættelse.
} 


\section{S. Troelsen}

mellem tekst og kontekst. Endelig ses teksternes dialog med konteksten $\mathrm{fx}$ i deiktiske referencer til situationskonteksten, spejling af opgavekrav samt intertekstuelle og stilistiske referencer til tekstkulturer og normkilder.

\section{Elevbesvarelserne i relation til eksisterende studier}

Det empiriske grundlag for undersøgelsen er 57 elevbesvarelser fra sommereksamen i maj 2017 fra en såkaldt paradigmatisk case (Flyvbjerg, 2010, s. 475) tilvejebragt gennem informationsorienteret udvelgelse (ibid.). Forud for indsamlingen af empiri er Caseskolen identificeret som en gennemsnitlig dansk skole på de parametre som registreres i Undervisningsministeriets Datavarehus (Undervisningsministeriet, 2016-17) - eksempelvis karakterfordeling ved afgangsprøverne og elevernes socioøkonomiske baggrund. I det følgende præsenteres det samlede materiale ud fra et overordnet perspektiv og sammenholdes med de resultater som kendes fra eksisterende forskning i elevers eksamenstekster.

Karaktererne for de 57 besvarelser er som nævnt fremkommet på baggrund af én beskikket censors bedømmelse. De udgør et empirisk udsnit fra den omtalte eksamensordning med påvist lav reliabilitet (Dolin et al., 2018). Den følgende sammenligning med eksisterende forskning skal altså ses i lyset af at samme korpus af tekster efter al sandsynlighed ville have været rangeret og vurderet anderledes i større eller mindre grad hvis censor havde været en anden. Som sådan deler undersøgelsen vilkår med den gældende praksis hvor eksamenskaraktererne trods den iboende usikkerhed anvendes som gyldige indeksikalske markeringer af en kvalitetsvurdering både i ministeriets statistikker og elevernes ansøgninger om videre uddannelse.

Caseskolen udmærker sig det aktuelle eksamensår ved karaktermæssigt at ligge lidt over landsgennemsnittet. Ingen elever dumper denne delprøve, og der er lidt flere i gruppen med middelkarakteren 7 end tilfældet er på landsplan.

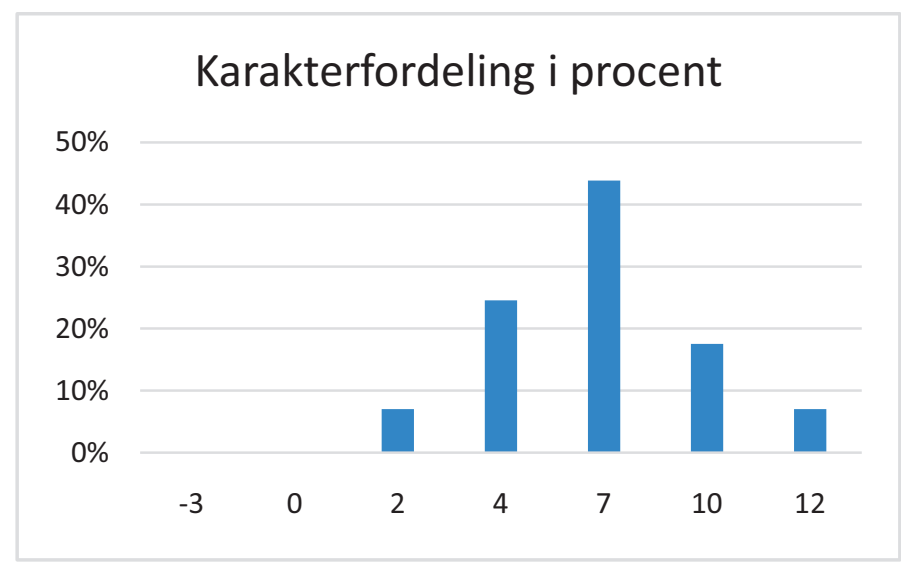

Figur 2. Karakterfordeling skriftlig fremstilling 2017 - Caseskolen (egne data). 
Elevernes tekster er svar på opgavematerialet (Undervisningsministeriet, maj 2017) en html-fil indeholdende generelle rammer for prøven samt fire skriveordrer, hver bestående af inspirationsmateriale og instruktion (Troelsen, 2018). Eleverne vælger én af fire skriveordrer, og det er almindeligt at bestemte opgavetyper appellerer til en stor gruppe elever mens andre er mindre populære - et mønster som bekræftes i eksisterende litteratur (Evensen \& Vagle, 2005; Rytter \& Stadelund, 2014). Caseskolens 57 elevtekster fordeler sig således genre- og indholdsmæssigt med 36 essays (ca. 2/3) om temaet "Digital mobning", 10 blogindlceg om at være "Strandet mellem Svendborg og Ærø”, 8 kommentarer til en ugebladsklumme under overskriften "Prins eller prinsesse?" og 3 baggrundsartikler om "Humor" (Figur 3).

\section{Opgavefordeling}

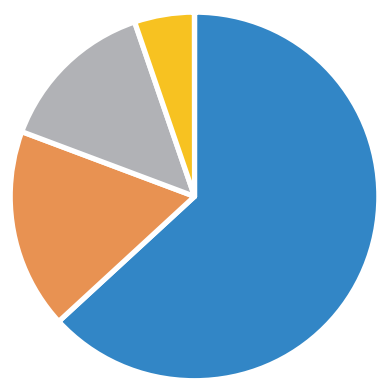

- 1 . Essay $\backsim 2$. Blogindlæg $\backsim 3$. Kommentar $\backsim 4$. Baggrundsartikel

Figur 3. Diagram over elevernes opgavevalg rubriceret efter genre.

Mønsteret i elevernes valg af emne og genre kan genfindes i eksisterende forskning, fx det norske projekt KAL (Kvalitetssikring av laringsutbyttet $i$ norsk skriftlig) (Berge, Evensen, Hertzberg, \& Vagle, 2005) som finder at eleverne foretrækker personlige og ofte narrative genrer frem for argumenterende og faktuelt formidlende. Dette bekræftes i de danske PEU-rapporter. ${ }^{4} \mathrm{Fx}$ valgte $80 \%$ af eleverne

\footnotetext{
${ }^{4}$ PEU-rapporterne (Prøver, Evaluering, Undervisning) udarbejdedes årligt til og med 2013 af Undervisningsministeriets fagkonsulenter og indeholdt blandt andet data om elevernes opgavevalg, karakterer og kønsfordeling. I forbindelse med dette studie har jeg henvendt mig til Undervisningsministeriet med ønske om adgang til tilsvarende data for 2017-terminen - helt konkret oplysninger om antal elever der har valgt de enkelte prøveemner (opgave 1-4), sammenhængen mellem opgavevalg og eksamenskarakter, sammenhængen mellem elevernes karakter i prøven i skriftlig fremstilling som det ene element og prøven i retskrivning som det andet og sammenhængen mellem køn og prøvekarakter. Ministeriet svarer i en mail fra 30. august 2019 at disse oplysninger ikke registreres p.t. Det er altså ikke muligt $\mathrm{fx}$ at undersøge hvorvidt bestemte emnevalg har betydning for elevernes muligheder for at få en god karakter.
} 


\section{S. Troelsen}

ved maj-prøverne 2013 genrerne novelle, essay og brev ud af seks mulige mens kun $20 \%$ valgte debatindlæg, kommentar og manuskript til en radioudsendelse (Rytter \& Stadelund, 2014). Hvis man på samme vis grupperer 2017-skriveordrens essay og fiktive blogindlæg (se også Troelsen, 2018) og tilsvarende samler den argumenterende kommentar og den sagsformidlende baggrundsartikel, er fordelingen på Caseskolen også omtrent 80/20. Der er altså tydelig overvægt af de personligt causerende og fiktive genrer på bekostning af de argumenterende og sagsformidlende. Dette modsvarer etnografiske studiers karakteristik af folkeskolens danskfaglige skrivekultur som domineret af personligt involverende, ekspressive skrivehandlinger med narrative og essayistiske genrer som de foretrukne og tilsvarende norske forhold (Berge et al., 2005; Christensen et al., 2014; Krogh, 2014; Otnes, 2015; Smidt, 2009). Tekstkulturen er således stabil hvad angår elevernes genrepræferencer.

Også karakterfordelingen i relation til skriveordrens genrer viser et element af forudsigelighed og ækvivalens med eksisterende forskning. Mens de talrige essays i sig selv repræsenterer en normalfordeling på karakterskalaen, samler blogindlæggene sig i skalaens nederste halvdel (02-7), baggrundsartiklerne i det nedre middelområde (4-7) og kommentarerne i området middel til godt (7-10) - dog uden egentlige topkarakterer (Tabel 1). Også dette mønster bekræfter større undersøgelser ikke mindst KAL-projektet der finder at ræsonnerende tekster (som her kommentaren) og L1-fagets klassiske skolegenrer som fiktionstekster og essays typisk vurderes højt af censorerne. En tentativ forklaring herpå kan være at de dygtige elever i højere grad foretrækker disse genrer. Men det kan også hænge sammen med bedømmernes tekstnormer ifølge hvilke eksempelvis ræsonnerende tekster repræsenterer et mere avanceret taksonomisk niveau end de narrative og formidlende genrer ligesom essayet og fiktionsteksterne muliggør udfoldelsen af personlig og kreativ stil (Berge, 2005b, p. 36). Kun essayopgaven har i denne case fået topkarakter. Om dette mønster kan genfindes på landsplan, er desværre umuligt at undersøge (jf. note 4).

Tabel 1. Oversigt over antal tekster i de forskellige genrer og de karakterer de fik ved afgangsprøven. De bedste karakterer gives for ræsonnerende tekster og essays.

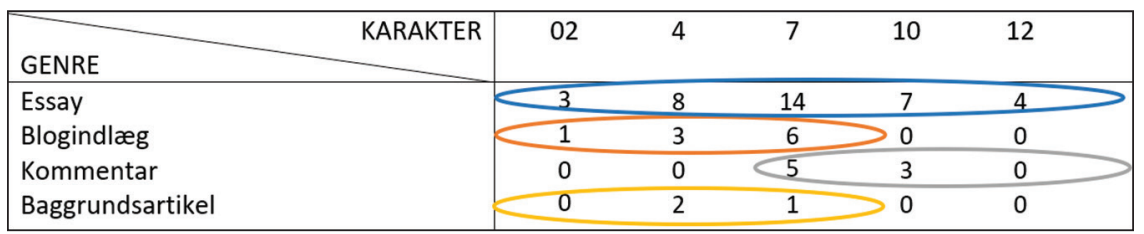

Caseskolens elevtekstkorpus bekræfter altså kvantitativt set mønstre iagttaget i andre studier og kan således betragtes som paradigmatisk for en skandinavisk skolekontekst og en danskfaglig skrivekultur som den er beskrevet i eksisterende forskning. 


\section{Empiri: Typificeringsudvalg og unikke tekster}

Den ovenfor beskrevne kortlægning af mønstre i tekstmaterialet udgør første fase $i$ en selektionsproces som overordnet set er forløbet som en zoombevægelse hen imod et intensivudvalg på 12 tekster med henblik på en nuanceret kvalitativ analyse. Teksterne er studeret ekstensivt med henblik på at identificere et kontinuum fra det netop accepterede som markerer grænsen for hvad der ifølge denne case anerkendes i tekstkulturen (karakteren 02), over den gennemsnitlige tekst (karakteren 7) og til den fuldt anerkendte (karakteren 12). Alle tekster med karakteren 02 eller 12 (fire af hver) er medtaget i intensivudvalget. Hertil kommer fire tekster som har fået middelkarakteren 7, den eneste karakter givet til besvarelser i alle skriveordrens fire genrer. Karaktererne er anvendt som umiddelbart sorteringskriterium fordi de indeksikalsk markerer tekstkulturens grad af anerkendelse. Derudover er bredden i materialet prioriteret ved at medtage besvarelser af alle fire skriveordrer - hvilket kun er muligt for tekster på middelniveauet. De fire tekster med karakteren 7 er udvalgt tilfældigt ved lodtrækning. Herefter er eleverne kontaktet og samtykke til videre brug af materialet herunder citat - indhentet. ${ }^{5}$ En oversigt over intensivudvalget findes i Tabel 2.

Tabel 2. Intensivudvalget af elevtekster.

\begin{tabular}{|c|c|c|c|c|c|c|}
\hline $\begin{array}{l}\text { Bilag } \\
\text { nr. }\end{array}$ & Titel & $\begin{array}{l}\text { Opgave } \\
\text { nr. }\end{array}$ & $\begin{array}{l}\text { Elev } \\
\text { (pseudonym) }\end{array}$ & $\begin{array}{l}\text { Karakter } \\
\text { ved FP9 } \\
2017\end{array}$ & $\begin{array}{l}\text { Kvantitativ } \\
\text { behandling og } \\
\text { indledende } \\
\text { screening }\end{array}$ & $\begin{array}{l}\text { Tilsagn til } \\
\text { citat og } \\
\text { videre } \\
\text { behandling }\end{array}$ \\
\hline- & Digital mobning & 1 & Lasse & 2 & $\mathrm{x}$ & - \\
\hline 1 & Digital mobning & 1 & Victor & 2 & $\mathrm{x}$ & $\mathrm{x}$ \\
\hline 2 & [Uden titel] & 2 & Emre & 2 & $\mathrm{x}$ & $\mathrm{x}$ \\
\hline- & Den nye mobning & 1 & Patrick & 2 & $\mathrm{x}$ & - \\
\hline 3 & $E L E V-I N D L A E G$ & 2 & Anna & 7 & $\mathrm{x}$ & $\mathrm{x}$ \\
\hline 4 & $\begin{array}{l}\text { Digital mobning. } \\
\text { Mobningen er flyttet } \\
\text { fra skolegården til } \\
\text { internettet }\end{array}$ & 1 & Ida & 7 & $\mathrm{x}$ & $\mathrm{x}$ \\
\hline 5 & $\begin{array}{l}\text { Danskerne er vilde } \\
\text { med ironi }\end{array}$ & 4 & Marika & 7 & $\mathrm{x}$ & $\mathrm{x}$ \\
\hline 6 & $\begin{array}{l}\text { Hvorfor må vi ikke } \\
\text { kalde vores børn for } \\
\text { "prinsesser"? }\end{array}$ & 3 & Veronica & 7 & $\mathrm{x}$ & $\mathrm{x}$ \\
\hline 7 & $\begin{array}{l}\text { Teknologiens } \\
\text { skyggeside }\end{array}$ & 1 & Emma & 12 & $\mathrm{x}$ & $\mathrm{x}$ \\
\hline 8 & $\begin{array}{l}\text { Mobning på digital } \\
\text { plan }\end{array}$ & 1 & Samira & 12 & $\mathrm{x}$ & $\mathrm{x}$ \\
\hline 9 & $\begin{array}{l}\text { Tcenk dig om en ekstra } \\
\text { gang }\end{array}$ & 1 & Asta & 12 & $\mathrm{x}$ & $\mathrm{x}$ \\
\hline 10 & Søndagsstuen & 1 & Ester & 12 & $\mathrm{x}$ & $\mathrm{x}$ \\
\hline
\end{tabular}

\footnotetext{
${ }^{5}$ To elever har ikke givet samtykke til citat og intensiv brug af teksterne. Patrick kunne ikke kontaktes, Lasse afviste. Disse elevers tekster er således kun studeret indledningsvis via forskeradgang til Caseskolens arkiv og indgår alene i den kvantitative kortlægning og den ekstensive screening med henblik på at danne et indtryk af tekstkulturens spændvidde. De analytiske iagttagelser fra disse to tekster begrænser sig således til de umiddelbare karakteristika som er nævnt i Figur 13.
} 


\section{S. Troelsen}

\section{Analyse}

Intensivudvalgets 12 tekster er analyseret efter konstellationsmodellen og repræsenterer altså casens typiske 02-, 7-, og 12-taller, så forskellige de end er. 02- og 12-tallerne markerer den såkaldte konstitutionsgrcense (Berge, 2012) som vel at mærke havde tegnet sig anderledes i det givne tekstkorpus hvis bedømmeren havde været en anden. ${ }^{6}$ I det følgende næranalyseres fire udvalgte elevtekster efterfulgt af en ultrakort præsentation af de øvrige otte. De fire repræsenterer forskellige tilgange til eksamensskrivningen som jeg betegner henholdsvis: Strategisk kreativitet, umiddelbar narration, intuitiv iscenescettelse og kulturkompetent kommunikation. Prioriteringen af få, men udfoldede analyser sker for med det tekstantropologiske udgangspunkt at komme tæt på unikke teksters meningsskabelse, eksplicitere elevernes tekstnormer og fremanalysere skriveridentitet. Af pladshensyn er kun den første af de fire analyser fuldt udfoldet - herefter er detaljeringsgraden faldende. Dette er dog udelukkende et formidlingsspørgsmål. De bagvedliggende analyser af de 10 tekster som forskeren har fået lov til at citere og bruge, er alle fuldt udfoldede. Indledningsvis i hver analyse præsenteres i konstellationsmodellens form en skematisk analyse af den skriveordre elevens tekst besvarer (analyseres udførligt i Troelsen, 2018). De ti tekster som eleverne har indvilliget $\mathrm{i}$ at lade mig anvende, er vedlagt artiklen som bilag (se bilagsnumre i Tabel 2).

\section{Anna - strategisk kreativitet}

Eleven Anna agerer både strategisk (Berge, 1988) og kreativt (Jakobsen, 2016) i sin eksperimenterende adressering af en kompleks skriveordre gennem anvendelse af multiple semiotiske resurser. Det vil jeg udfolde i det følgende.

\section{Den sociale handling}

Anna har besvaret opgave 2, Strandet mellem Svendborg og Arø (Figur 4) (se også Troelsen, 2018). Skriveordren inviterer via et formodet genkendeligt scenarie (unge i fælles tidsfordriv i en moderat dramatisk situation) eleven til at realisere skriveglæde i en tidssvarende genre. Elevskriveren skal forestille sig at være blandt de efterskoleelever som i 2011 måtte overnatte ombord da færgen mellem Svendborg og Ærø stødte på grund, og skrive "indlæg til din skoles blog om dine oplevelser og tanker ombord på den strandede færge". ${ }^{7}$ Elevskriveren må altså indtage en fiktiv afsenderposition

\footnotetext{
${ }^{6}$ Lav bedømmerreliabilitet er almindelig for skriveprøver (Berge, 2005a), og i den gældende danske ordning med kun én bedømmer er den generelle reliabilitet følgelig også lav (Dolin et al., 2018, s. 16). Når karaktererne i denne undersøgelse alligevel bruges til at tegne tekstkulturens bund, midte og top, skyldes det at de ikke desto mindre udgør de faktiske eksamenskarakter på Caseskolen og i praksis danner grundlag for elevsortering i uddannelsessystemet samt statistisk sammenligning af skoler på Undervisningsministeriets hjemmeside.

${ }^{7}$ Her nævnes kun den verbale instruktion, men faktisk kommunikeres der tvetydigt om den fiktive afsenderposition idet den tilhørende fotoillustration forestiller færgen set fra land (Troelsen, 2018).
} 


\begin{tabular}{|c|c|c|c|}
\hline $\begin{array}{r}\text { Analyseper- } \\
\text { spektiv }\end{array}$ & Tekst & Fagdiskurs & Social handling \\
\hline Skriveordren & $\begin{array}{l}\text { Fiktiv rammesætning } \\
\text { Den 27. november } 2011 \text { går færgen } \\
\text { "Arøskøbing" på grund i farvandet mel- } \\
\text { lem Svendborg og Atø. Ombord er blandt } \\
\text { andet en mindre gruppe efterskoleelever } \\
\text { på vej til deres skole. Forestil dig, at du er } \\
\text { en af disse elever. } \\
\text { Du vælger at skrive indlæg til skolens } \\
\text { blog, mens færgen er grundstødt. } \\
\text { Skriveordre } \\
\text { Skriv tre-fire indlæg til din skoles blog om } \\
\text { dine oplevelser og tanker ombord på den } \\
\text { strandede færge. } \\
\text { Du skal blandt andet: } \\
\text { søge informationer om begivenheden } \\
\text { på internettet } \\
\text { skrive om } \\
\text { - forløbet og stemningen om bord } \\
\text { - reaktioner blandt passagererne } \\
\text { - besætningens håndtering af situ- } \\
\text { - ationen } \\
\text { give de enkelte blogindlæg over- } \\
\text { skrifter. }\end{array}$ & $\begin{array}{l}\text { Hverdagsdis- } \\
\text { kurs om } \\
\text { skrivning: } \\
\text { "skrive om", } \\
\text { "give... en ti- } \\
\text { tel" } \\
\text { Genren "din } \\
\text { skoles blog" } \\
\text { er en genre } \\
\text { med vage } \\
\text { genrekoder } \\
\text { og uklar } \\
\text { adressat. } \\
\text { Fiktiv blog } \\
\text { med krav om } \\
\text { informati- } \\
\text { ons } \varnothing \text { gning } \\
\text { og faktisk } \\
\text { indhold. }\end{array}$ & $\begin{array}{l}\text { Positionerer ele- } \\
\text { ven dobbelt ift. } \\
\text { ekspressivitet, re- } \\
\text { ferentialitet og } \\
\text { adressivitet og er } \\
\text { dermed kompli- } \\
\text { ceret. } \\
\text { Flertydig multi- } \\
\text { modal kohæsion } \\
\text { => uklar positio- } \\
\text { nering af afsen- } \\
\text { deren. }\end{array}$ \\
\hline
\end{tabular}

Figur 4. Skriveordrens opgave 2 i konstellationsmodellen.

(Otnes, 2013) og adressere en ligeledes fiktiv (og ikke eksplicit defineret) modtagergruppe. Til gengæld er tekstens referentialitet - elevens "tanker og oplevelser" delvist styret af opgavens stilladsering hvorefter eleven skal skrive om helt specifikke forhold som der skal søges oplysninger om på internettet: "forløbet og stemningen ombord, reaktioner blandt passagererne, besætningens håndtering af situationen”. I forhold til besvarelsens ekspressivitet, referentialitet og adressivitet positioneres elevskriveren således relativt abstrakt og kompliceret (Troelsen, 2018):

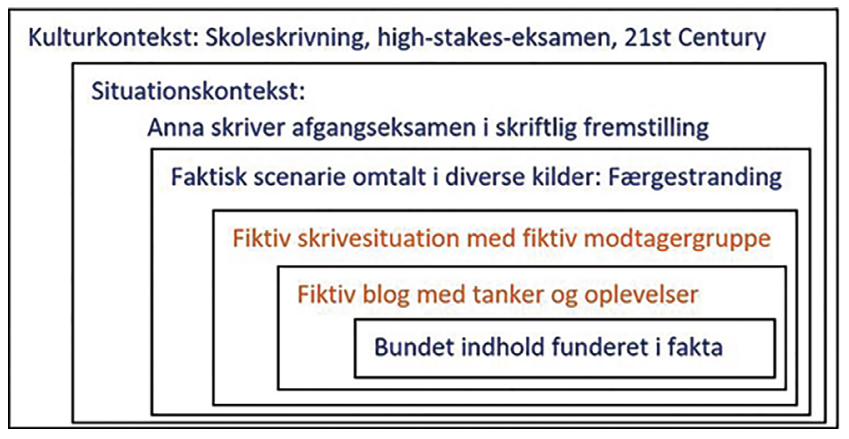

Figur 5. Skriveordrens rammesætning af faktiske og fiktive lag. 


\section{S. Troelsen}

Anna adresserer omhyggeligt alle formulerede krav. Hun anvender i sin multimodale tekst et bredt udvalg af semiotiske resurser og markerer fx tydeligt i layoutet tekstkonfigurationer på flere niveauer. Således indrammer hun ved hjælp af de obligatoriske teksttcerskler (Togeby, 2015, p. 269) ${ }^{8}$ de tre fiktive blogindlæg og spejler herved skriveordrens rammesætning af en fiktiv situationskontekst (jf. Figur 6).

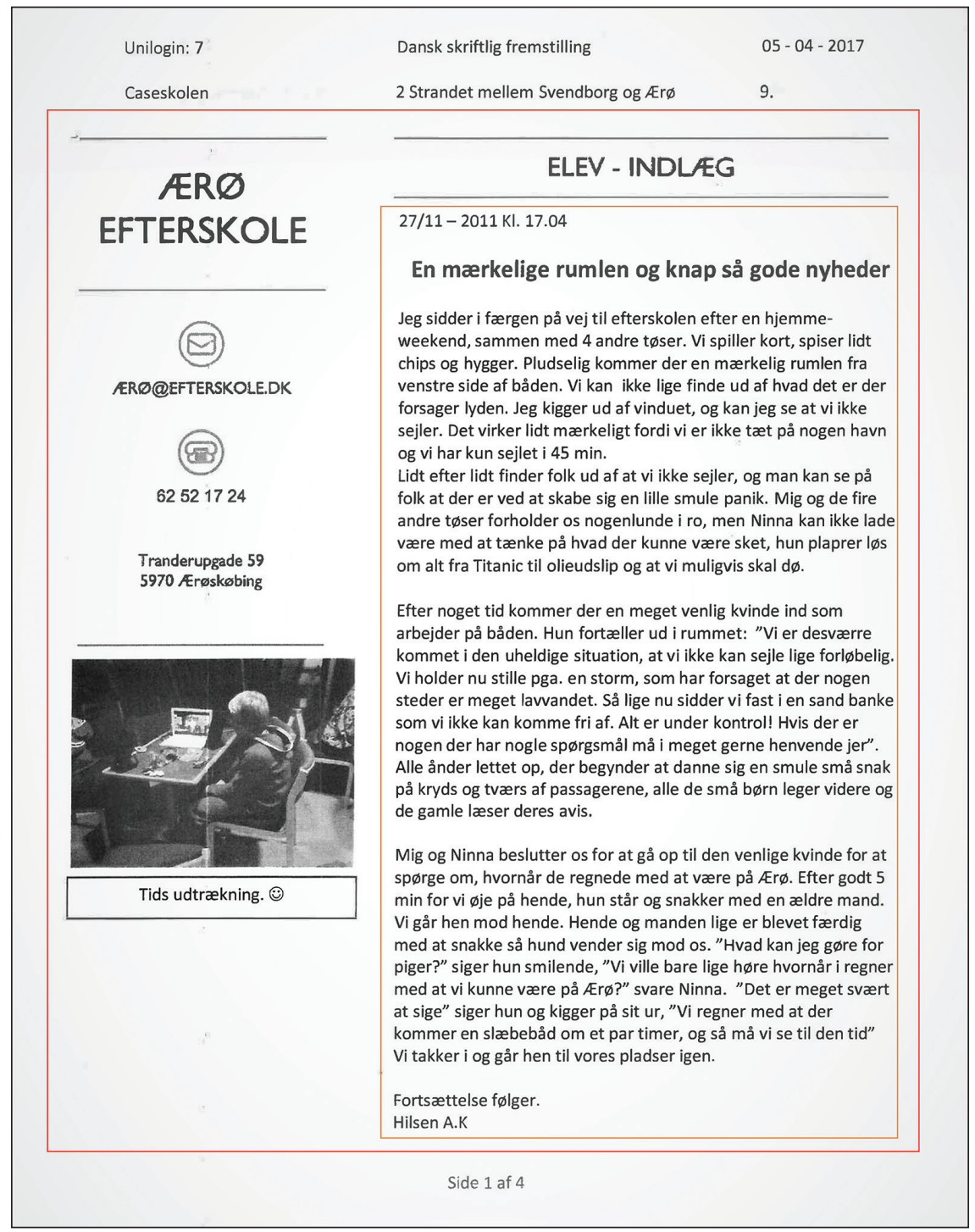

Figur 6. Første side af fire, Annas tekst (bilag 3). Udenfor min røde markering findes teksttærsklerne som indrammer den fiktive blog bestående dels af endnu en ramme i form af bloglayoutet, dels første blogindlæg (orange markering).

${ }^{8}$ I dette tilfælde: sidehoved med elevens eksamens-id, skolens navn og nummer, prøvenavn, dato, klasse og den valgte opgaves navn og nummer, sidefod med sidenumre og en kildeliste på sidste side. 
Strukturen ligner fiktionslitteraturens rammefortællinger hvor det fortalte indrammes af en iscenesat udsigelsessituation (se fx Rømhild, Den store danske), og betydningen netop udfoldes $i$ spendingen mellem rammen og det indrammede. ${ }^{9}$ Yderst repræsenterer Anna sig selv som skriver samt den situerede sociale handling som er afsæt for den fiktive blog. Her anerkender hun fx med sine tre kildereferencer til etablerede danske medier og behandlingen af de dér fundne oplysninger præmissen om at søge oplysninger på internettet selvom dette næppe er nødvendigt for at videregive "tanker og oplevelser" fra en fiktiv position. Anna agerer på dette niveau strategisk og rituelt (Berge, 1988) som sit selvbiografiske selv (Ivanič, 2012) idet hun overfor censor, som er tekstens empiriske læser, signalerer accept af rammerne og honorerer de formelle krav i den tekstkultur hun skriver sig ind i. Som skriveordren fordrer, konstruerer hun et dobbelt diskursivt selv idet hun både fremtræder som afsender af elevteksten som social handling og installerer et fiktivt afsendersubjekt der inden for fiktionen repræsenterer et indhold og adresserer en fiktiv modtagergruppe. Det skal hun vel at mærke gøre på en måde som den reelle adressat vil værdsætte (se også Troelsen, 2018), og det krav honorerer hun ved i den indrammede tekst at identificere sig med den fiktive situationskontekst: Efterskoleelev på strandet færge skriver indlæg til publicering på efterskolens blog med den målgruppe en sådan nu måtte have. Det ser vi nærmere på med linsen vendt mod Annas besvarelse som tekst.

\section{Teksten}

Besvarelsen er udpræget multimodal og den af casens 57 elevtekster som anvender flest modaliteter funktionelt og gennemført. Som sådan er den udtryk for Annas bevidste fremstilling af tekst - jf. læreplanens kompetenceområde af samme navn og prøvens navn - gennem sammenstilling af forskellige komposita. Fremstillingsmetaforen ${ }^{10}$ modsvarer Ivanič' begreb wrighting - stavet med "gh" og med allusion til ord som "cartwright" - som betegner et håndværk (Ivanič, 2012), og indfanger den omhu og kreativitet (Jakobsen, 2016) hvormed Anna omhyggeligt selekterer og anvender forskellige repræsentationsformer til at komponere en tekst der modsvarer skriveordrens krav. Den globale konneksion forstået som samspillet mellem forskellige elementer er denne teksts fundament og anvendes til at udfolde skriveordrens fordringer diskursivt. Mediet ("din skoles blog") repræsenteres i layoutets imitation af en skoleblog. Anna lader efterskolen i den fiktive case være "Ærø Efterskole" og indarbejder i layoutet skolens navn og kontaktdata i et gennemgående lodret bånd i venstre margen. Øverst findes en bjælke med teksten "ELEV-INDLÆG" som illuderer at man befinder sig på en underside med denne fane. ${ }^{11}$ Herunder er tekstindlæggene placeret - ensartede i størrelse og indledt med præcis tidsangivelse modsvarende begivenhedsforløbet.

\footnotetext{
${ }^{9}$ Kendte eksempler fra verdenslitteraturen kunne være Giovanni Boccacios Dekameron (1353) eller Joseph Conrads Heart of Darkness (1902).

${ }^{10}$ For en udfoldet gennemgang af begrebet "skriftlig fremstilling" se Troelsen (2018).

${ }^{11}$ En søgning viser at Ærø Efterskoles hjemmeside ikke ser ud som Annas. Om det skyldes at skolen har skiftet weblayout siden, eller om Annas layout er et kreativt påfund, vides ikke.
} 


\section{S. Troelsen}

Nederst i venstre side har Anna placeret fotos fra kildelistens avisomtaler af strandingen og tilføjet billedtekst i ramme - på side 1 og 2 med en emoji som kommentar og signal om at billedteksten har en anden status i denne tekst end i fx en avisartikel.

Annas fiktive blog er komponeret af tre prosaindlæg indsat i en ramme (jf. Figur 6) som illuderer hjemsted for en weblog, og forankret $i$ et her og nu. Blogindlæggene behandler kronologisk og i narrativ form forløbet fra passagererne aner uråd (under overskriften "En mærkelige [sic!] rumlen og knap så gode nyheder”) over en ufrivillig overnatning ("En hyggelig aften og trætte passagerer") og til situationens opløsning ("Kurs mod Ærø og efterskolen”). På dette niveau er indramningen en diskursiv manifestation af den simulerede eller fiktive skriverposition med reference til faktisk tid, sted og rum som skriveordren fordrer, og Anna demonstrerer herigennem kendskab til bloggens genrekoder - også i grænsefladen mellem tekst og kontekst. Bloggenren tager form i et dialogisk forhold mellem afsender, modtager og medie (Miller \& Shepherd, 2004) hvilket Anna mimer indenfor den fiktive ramme, og den fiktive situationskontekst er diskursivt repræsenteret flere gange. Eksempelvis afsluttes hvert indlæg med en hilsen til læserne. Den første "fortsættelse følger. Hilsen A. K" fungerer som cliffhanger. Den anden "der kommer en indberetning [sic!] i morgen, sov godt! Hilsen A. K" gør varieret det samme, nu direkte henvendt til læseren og markerende det fælles nu hvor læseren er på vej i sin egen seng mens eleverne må overnatte på færgen. Den sidste "Vi ses. knus A. K” markerer forløbets afslutning, den snarlige genforening og en vis lettelse.

I de enkelte blogindlæg veksler fremstillingsformen stilistisk mellem fiktionens historiske præsens i scenisk fremstilling og en mere rapporterende panoramisk stil som passer bedre til bloggens situationskontekst. Fiktionsinspirationen afspejler at Anna udfordres af skriveordrens kontrakt om at skrive faktatekst i en fiktiv rammesætning og fristes til at trække på litterære forlæg - især i det første indlæg hvor afsnitsinddelingen markerer tydelige sceniske nedslag med tidslige ellipser imellem. Navnlig tidsadverbierne peger her mod fiktionens relation mellem fortæller og fortalt og installerer distance mellem det fortællende og det deltagende jeg: "Pludselig", "Lidt efter" og "Efter noget tid". Venindens rolle i teksten bliver at formidle de følelser jegfortælleren ikke selv beretter om: "Ninna kan ikke lade være med at tænke på hvad der kunne være sket, hun plaprer løs om alt fra Titanic til olieudslip og at vi muligvis skal dø”, og på samme måde bruges personalets replikker og skildringer af de øvrige passagerers ageren til at formidle stemninger og følelser ombord. Det er en tempofyldt og mættet beskrivelse af den nervøse stemning, showing snarere end telling. I andet indlæg lykkes det i højere grad Anna at fastholde den fiktive positionering som blogger ombord på færgen. Her tager hun udgangspunkt i et her og nu ud på aftenen hvor det står klart at færgen ikke kommer fri før den følgende dag. Accepterer man at hun kan skrive med den sovende venindes hoved i skødet (og det må man gøre i mobiltelefonens tidsalder), brydes illusionen kun til allersidst hvor forfatterjeget zoomer væk fra det fortalte: "Jeg får forsigtig flyttet Ninna fra mit skød, går hurtigt på toilet og finder der efter nogle tæpper til mig og de andre tøser”. I sidste blogindlæg har Anna fundet stilen og fastholder fokus på skrivesituationens her og nu. Færgen er atter i bevægelse, og hun reflekterer over 
stemningen og sin egen længsel efter at komme hjem. Hun getter nu på hvad "de andre tøser" mener uden at lade sig friste af fiktionens indresyn, og sanseindtryk kobles på den reflekterende, skrivende blogger og ligner ikke længere fiktion: "Jeg sidder i vindueskarmen og kigger ud, solen skinner, men der kommet lidt is på ruden så det er nok også rigtig koldt. Lidt ude i det fjerne kan jeg se en båd (...)”.

\section{Fagdiskursen}

Anna positionerer sig autorialt som både myndig og kyndig tekstproducent: Som nævnt ovenfor går hun i dialog med skriveordren på dennes præmisser som blandt andet indebærer en overordentlig kompleks udsigelsesstruktur. Anna diskursiverer i sin tekst både stemning og fakta og honorerer derigennem fordringen om at videreformidle "oplevelser og tanker" og samtidig basere disse på informationssøgning på internettet. Fagdiskursen fiktiv blog udfolder diskursivt bloggenrens "social action" som talerør for en subjektiv afsender der i et eksplicit indskrevet her og nu beretter til en indviet modtagergruppe. Bloggen består af hyppige, korte indlæg og skrives i præsens ligesom dagbogsnotater. Og den semiotiske resurse tidsangivelse anvendes funktionelt til at markere hændelsesforløbets udstrækning og er desuden et af bloggens få formelle genretræk (Miller \& Shepherd, 2004). Dog vil kronologien i en weblog typisk være omvendt således at læseren møder det seneste indlæg øverst på siden (Miller \& Shepherd, 2004) mens de øvrige rykker nedad efterhånden. Annas mere narrative og dagbogsinspirerede kronologi skal snarere ses i relation til den fiktionsfortæller som taler med i hendes tekst (jf. ovenfor) der således også har skønlitteraturen som faglig normkilde.

På tekstens mikroniveau folder Anna sig ud og eksperimenterer på trods af at det af og til bringer hende ud i ukonventionel stavning. ${ }^{12}$ Omvendt håndteres udfordrende stavemåder uden problemer i de fleste tilfælde. ${ }^{13}$ Anna demonstrerer risikovillighed i sit eksperimenterende og varierede ordvalg, og interpunktionen er overvejende sikker med kommaerne som den eneste udfordring. Hun affilierer sig således ikke med en forsigtig korrekthedsdiskurs, ${ }^{14}$ men positionerer sig som eksperimenterende og erfaren skriver og imødekommer skriveordrens invitation til kreativitet og bloggenrens her-og-nu-situationskontekst. ${ }^{15}$

\section{Emre - umiddelbar narration}

Emre konstruerer sit skriverselv $i$ en umiddelbar, lystfyldt narration som ignorerer eksamenssituationens alvor og forholder sig særdeles selektivt til skriveordrens krav bortset fra det helt basale at den tjener som initierende moment og inspiration.

\footnotetext{
12 Se bilag 11.

${ }^{13}$ Fx "fiskefileter", "egentlig", "Bezzerwizzer" og "sejlende".

${ }^{14}$ Lillis hævder at evalueringsregimer som betragter skrivning ift. en implicit korrekthedsnorm, dominerer, og at forskere selv er indlejret i sådanne regimer (Lillis, 2018). Jeg forsøger her at indtage et andet synspunkt og i stedet pege på en korrekthedsdiskurs som én blandt flere diskurser som elevskriverne enten kan ignorere, forholde sig selektivt til eller affiliere sig med.

${ }^{15}$ Havde Anna prioriteret korrekthedsdiskursen, kunne hun ved anvendelse af stavekontrollen have undgået 7 ud af 21 ortografiske fejl.
} 


\section{S. Troelsen}

\section{Den sociale handling}

Også Emres tekst (Figur 7) besvarer opgave 2 (Figur 4), men den er fundamentalt forskellig fra Annas - fra det globale til det lokale niveau. Emre går kontekstløst og fabulerende til skrivningen med en tekst helt uden teksttærskler. Besvarelsen

\section{Cyklen}

Solen skinner, det blæser dog lidt. Kasper er i gang med at snakke med hans mor angående sejlturen til Ærøskøbing, han er mors dreng. Klokken er 16:58, Kasper, Karen, Villy og jeg venter på Morten, som skal med hen til vores efterskole. Så kommer han kraftedme siddende på en cykel, og den må ikke med ombord. "Hvad så drenge" siger han, vi andre kan ikke lade være med at grine, "amen din kraftidiot, har du ikke lige købt den cykel” siger Villy, “Jo, og hvad så? ” siger han så, " ha ha ha, du må ikke tage den med ombord, der er nye regler" siger Karen, vi alle griner undtagen Morten som kigger fornærmet på os "oh fuck, hvad fanden gøre jeg nu! " vi stopper med at grine, vi kan se at han bliver en lille smule ked af det, fordi cyklen er splinter ny. Vi får så den ide, at vi smugler cyklen ind uden nogen ser det. Klokken er 16:03, og vi skal ombord, færgen sejler om to minutter, og den cykel skal bare ind. Der er to indgange, en til passagerne og en til personale. Planen er at Morten og Villy tager personale døren og vi tager den anden, mens vi distrahere personalerne ombord. Kasper, Karen og jeg går ind, vi sætter os, og nu venter vi bare på Villy og Morten. "Fuck, hvad med hvis de er blevet taget! " siger Karen, "så længe Villy er der, sker der ikke noget”. Villy har altid været "Einstein" i gruppen. Nu kommer de, de kommer grinende og glad, vi alle begynder med næsten at dø af grin, og vi har ikke en ide om hvad vi griner af.

\section{Smøgen}

Nu sidder vi og hygger, vi har købt nogle snacks og en sixpack af kolde red Bulls. Det tager fem og halvfjerds minutter at ankomme til Ærøskøbing, så vi spilder tiden ved at spille kort og snakke sammen. Karen kan ikke lige at sejle, han bliver søsyg, og ender med at kaste hans mors gode lasagne op gentagne gange, mens vi andre gemmer os og griner lidt, men det ligger han selvfølgelig mærke til, og kaster op over Kasper, vi andre griner højlydt, men Morten bliver meget sur og fornærmet "Hvad fuck har du gang i, Karen. Min mor har lige købt denne her trøje, din idiot! " "Du kunne da bare lade være med at grine" siger Karen, mens dig bliver spyttet hans mors lasagne ud. "Ej, nu kan jeg ikke mere, jeg skal fandme have en smøg" siger Villy, "Så gå dog ud og tag en, der er sgu ingen der holder dig", "ud? haha, jeg tænder den her min ven", Selvom Villy var den klogeste, kan han engang imellem godt være med til lidt drengerøve. Han tager hans Marlboro gold pakke frem, tager en smøg og tænder den. De andre passagerer kigger irriteret og ondt på os, men de ved hvem vi er, de ved at hver sejltur med Ærøskøbing færgen, ikke skal sejle uden lidt drengerøve. Vi andre fniser og Villy nyder bare sin smøg, men nu kommer personalet fandme. Villy skynder sig at slukke den, "oh nej drenge, det er ham fra sidst" siger jeg, "er det nu jer igen? sig mig hvad fanden har i gang i! i skal sguda ikke tænde en smøg herinde! " vi stirre på hinanden, men siger intet, "en fejl mere, og jeg kaster jer fandme ud af færgen, så må i svømme hjem! ”, vi holder bare kæft, for den mand kan fandme godt finde på det. Så Villy gik bare ud og røg, mens vi andre spiller kort, for nu er der en halv time tilbage.

Figur 7. Første side af to, Emres besvarelse (bilag 2). 
savner både de obligatoriske data og kildelisten der semiotisk repræsenterer søgning på internettet. Det anonyme prøve-id er skrevet på med kuglepen af eksamensvagten (men fjernet i min gengivelse), og Emre undlader dermed både at adressere eksamenssituationen og at konstruere den fordobling af det diskursive selv som eksamensskrivningen kræver (Troelsen, 2018), og tekstens konfiguration er uklar.

Implicit findes en række semiotiske markeringer af teksten som svar på skriveordren: Kompositorisk består den som krævet af tre afsnit med hver sin rubrik, indholdsmæssigt møder vi fem efterskolekammerater, medpassagerer og personale på færgen, og referencer til Ærøfærgens nøjagtige overfartstid og afgangstidspunkt indikerer at der er søgt informationer på nettet. Men den afgørende begivenhed strandingen der varer en hel nat - er udeladt hvilket udgør en væsentlig afvigelse i forhold til skriveordrens krav. Samlet konstruerer Emre sit diskursive selv næsten uden skelen til skriveordren og prøvens kultur- og situationskontekst. Det betyder imidlertid ikke at hans tekst ikke reflekterer skolekonteksten - blot trækker han på skønlitterære og populærkulturelle normkilder. ${ }^{16}$ Layoutet signalerer snarere prosa i bogform end blog med enkeltindlæg. Den anvendte typografi kendes fra romanudgivelser, og de regelmæssige tekstblokke minder mere om fx 1990'ernes kortprosa, Louis Jensens firkantede historier eller visse ungdomsromaner med korte kapitler. ${ }^{17}$

\section{Teksten}

At dømme ud fra de intertekstuelle allusioner i Emres skrift er normkilden især nyere ungdomslitteratur der ofte udfolder et dagbogslignende format hvor en ung jegfortæller beretter i præsens om ungdomslivets temaer. Første afsnit, "Cyklen”, starter in medias res og introducerer implicit et persongalleri bestående af jegfortælleren og fire andre drenge. Hovedtemaet er drengenes venskab ("mine bedste venner") i opposition til omgivelserne manifesteret i først et cykeltyveri (loven), så brydninger med personalet på færgen (autoriteter) og til sidst efterskolens regler (skolen). I tre episoder der fungerer som selvstændige kapitler, skildres fællesskabet omkring "lidt drengerøve" og det indbyrdes samvær med smådrillerier og samtidig ufravigeligt sammenhold internt i gruppen hvor man hjælper hinanden med alt fra at skjule stjålne cykler til at få klaret den tyske stil.

\footnotetext{
${ }^{16}$ Datamaterialet og dette studies fokus umuliggør referencer til konkrete elevers danskundervisning, men studier i fx læremidler til danskfaget identificerer en dominerende tekstkultur som vægter fiktion højt især i udskolingen (Bundsgaard, Buch, \& Fougt, 2017).

${ }_{17}$ Alle tre eksempler indgår ofte $\mathrm{i}$ folkeskolens danskundervisning og gribes altså af Emre som inspiration.
} 


\section{S. Troelsen}

Kohærensen brydes lejlighedsvis, fx når den cykel der fylder meget i første afsnit, helt glemmes i sidste, og i navneforvirring om hvis tøj der kastes op på pga. søsyge. Men overordnet fungerer den tredelte komposition struktureret over tekstens topik: Fra afgang i Svendborg over sejlturen og til ankomsten til Ærø og efterskolen. Stilistisk viderefører teksten ungdomslitteraturens tradition for persontegning gennem handlinger, relationer og replikker. Både jegfortælleren og vennerne bruger en del kraftudtryk, og i replikkerne markeres talesprogsudtale - fx "amen din kraftidiot". Herudover tegnes personerne gennem relationer til $\mathrm{fx}$ deres mødre (der laver lasagne til dem eller misbilliger pletter på tøjet), og deres rolle i gruppen ("Villy har altid været 'Einstein' i gruppen').

Ortografi og interpunktion anvendes funktionelt, og elektronisk stavekontrol sikrer at kun få fejl som denne ikke fanger, står tilbage. ${ }^{18}$ Semantiske forvekslinger indikerer at dansk kunne være Emres andetsprog. ${ }^{19}$ Eksempelvis hedder den ene af tekstens fem drenge "Karen" (pigenavn), "drengerøve" bruges frem for "drengestreger", og idiomer forveksles: "spilder tiden" anvendes i stedet for "fordriver tiden". Dertil findes kontekstuelle tegn på at enkeltbegreber er ukendte for Emre. At jegfortælleren vægrer sig ved at skulle tilbage til efterskolen, er således påfaldende for en kender af dansk efterskolekultur, og fraværet af skriveordrens afgørende element, strandingen, skyldes formentlig begrænset ordkendskab og dertil manglende bevidsthed om og strategier til at håndtere manglende forståelse (Bråten, 2008).

\section{Fagdiskursen}

Emres tekst har som nævnt snarere visse ungdomsromaner og -fortællinger i diverse medier som normkilder end bloggenren, og han positionerer sig autorialt som umiddelbar narrator hvis fortælling bæres af hans egen lystfyldte identifikation med det fiktive univers han konstruerer. Hvor layoutet kunne anvendes til at simulere en digital tekst, har Emre snarere imiteret papirbogen, og dette gøres med omhu helt ned i interpunktionen. Dertil ses spor af bloggens genretræk sådan som Miller og Shepherd definerer dem (2004), i tidsangivelserne: "16:58", "16:03" og "cirka seks".

\section{Ester - intuitiv iscenesættelse}

Esters konstruktion af skriverselv er præget af en intuitiv performance som snarere er rituel end strategisk i Berges terminologi (Berge, 1988), og vidner samtidig om en vis distancering eller iscenesættelse.

\footnotetext{
${ }^{18}$ Se bilag 11.

${ }^{19}$ Jeg har ikke andre data om eleverne end navnet som i dette tilfælde peger på en dreng med tyrkisk ophav.
} 


\begin{tabular}{|c|c|c|c|}
\hline $\begin{array}{r}\text { Analyseper- } \\
\text { spektiv }\end{array}$ & Tekst & Fagdiskurs & Social handling \\
\hline Skriveordren & $\begin{array}{l}\text { Manchet med inspirationsfilm } \\
\text { Center for Rummelighed har produceret en } \\
\text { film, hvor de har bedt } 12 \text { gæster læse autenti- } \\
\text { ske mobbebeskeder op. Gæsteoplæserne har } \\
\text { ikke set beskederne før, og deres reaktioner er } \\
\text { tankevækkende. } \\
\text { Skriveordre } \\
\text { Se filmen som inspiration, og skriv et essay } \\
\text { om digital mobning. } \\
\text { I dit essay skal du blandt andet: } \\
\text { - reflektere over, hvorfor mobning starter } \\
\text { beskrive, hvordan det påvirker den en- } \\
\text { kelte og samfundet } \\
\text { overveje, hvad der kan gøres for at mod- } \\
\text { virke mobning. } \\
\text { Giv dit essay en titel }\end{array}$ & $\begin{array}{l}\text { Essay. Traditi- } \\
\text { onel danskfag- } \\
\text { lig skolegenre } \\
\text { med afsæt i } \\
\text { personlige } \\
\text { tanker og } \\
\text { hverdags- } \\
\text { kundskab. } \\
\text { Relevante } \\
\text { skrivehandlin- } \\
\text { ger stilladse- } \\
\text { res i punkt- } \\
\text { form: } \\
\text { "reflektere", } \\
\text { "beskrive" og } \\
\text { "overveje". } \\
\text { Intet krav om } \\
\text { informations- } \\
\text { søgning. }\end{array}$ & $\begin{array}{l}\text { Positionerer eleven } \\
\text { som umiddelbar, } \\
\text { kommunikativt ori- } \\
\text { enteret skribent. } \\
\text { Autentisk kommu- } \\
\text { nikationsstruktur } \\
\text { hvor eleven kan } \\
\text { skrive som sig selv, } \\
\text { om egne erfaringer } \\
\text { og til en konkret } \\
\text { modtager (censor) } \\
\text { som samtidig re- } \\
\text { præsenterer en } \\
\text { mere abstrakt } \\
\text { modtagergruppe. }\end{array}$ \\
\hline
\end{tabular}

Figur 8. Skriveordrens opgave 1 i konstellationsmodellen (jf. Troelsen, 2018).

\section{Den sociale handling}

Som de fleste andre elever har Ester besvaret opgave 1 (Figur 8) og skrevet et essay om digital mobning efter at have set en kampagnefilm som inspiration. Essayet er en kanonisk (Berge, 2008) skolegenre og kendetegnet ved skribentens prøvende og associative overvejelser i feltet mellem litterær inspiration, personlig erfaring og samfundsdebat. ${ }^{20}$ Genren er som opgavens tema velkendt for eleverne der uden videre og med afsæt i egne erfaringer kan gå i gang med at skrive - i dette tilfælde uden krav om søgning på internettet. Det er således muligt for elevskriveren at konstruere sit diskursive selv som umiddelbar, kommunikativ skribent uden den store kompleksitet i udsigelsesstrukturen idet eleven kan skrive som sit selvbiografiske selv, om egne tanker og erfaringer og til en censor med baggrund som dansklærer og dermed deltager i fagets normfællesskab.

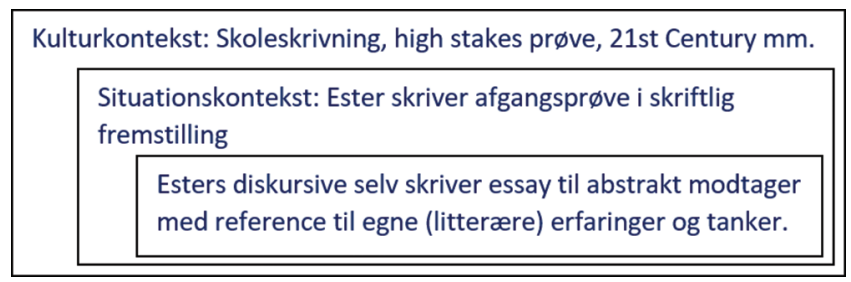

Figur 9. Udsigelsesstrukturen i elevbesvarelsen af opgave 1.

${ }^{20}$ Jf. fx Borup Jensen (Jensen, 1999), men også afspejlet i meget anvendte læremidler som eksempelvis dansk.gyldendal.dk. 


\section{S. Troelsen}

Også Ester konstruerer et fordoblet diskursivt selv som via teksttærsklerne indforstået anerkender prøvekonteksten og dens præmisser. Sidehoved og sidefod indeholder de påkrævede oplysninger, og afsluttende optræder en kildeliste selvom netop essayopgaven adskiller sig fra de øvrige ved ikke at kræve søgning på internettet. Ester anvender enkeltelementer fra begge angivne (velvalgte) kilder selektivt til inspiration for sit essay og signalerer således fagligt overskud gennem kildelisten.

Layoutet som semiotisk resurse demonstrerer genrekendskab og imødekommelse af skriveordrens krav ("Giv dit essay en titel") ved tydeligt at markere titlen "Søndagsstuen" hvis betydning først afsløres sidst i teksten. Men også på dette punkt er kravene i opgave 1 mindre komplicerede end i opgave 2, og Ester klarer sig med standardopsætningen i Word - med skrifttypen Times New Roman og den præindstillede overskrifttypografi. Hun har næppe ofret layoutet mange tanker - eksempelvis er automatisk orddeling ikke slået til.

\section{Teksten}

Kompositorisk består Esters tekst af seks afsnit med forskellige funktioner: 1) Scenisk tilbageblik på en erindring fra 5. klasse, 2) introduktion til fænomenet digital mobning, 3) eksempel på mobning fra skriverens hverdag i nu 9. klasse, 4) refleksionsafsnit om episoden i 5. klasse, 5) endnu et refleksionsafsnit om generelle konsekvenser af digital mobning og 6) scenisk refleksionsrum med udblik til fremtiden som også kan opfattes som mere panoramisk ("om søndagen") og dermed åbner for et generelt perspektiv.

Afsnittene 2, 4 og 6 afsluttes alle med retoriske spørgsmål der inddrager læseren i skriverens refleksive rum, og de sceniske nedslag i fortid, nutid og fremtid indrammer et erkendelsesforløb og forankrer det i det skrivende jegs erfaringer og fremtidsdrømme.

Ordvalget er varieret og kreativt, skildringerne sanselige ("Som en flue på væggen smuglyttede jeg diskret, men da ord som homo, luder og bitch blev læst op, fik jeg en krumme fra min rugbrødsmad galt i halsen") og originale ("Pigerne (...) blev med øjnene enige om at fortsætte snakken ude på gangen”) og forløbet båret af refleksion frem mod visionen om en mere hensynsfuld verden. Samtidig med at denne skrives frem, sker en overskridelse af essayets referentielle faktakontrakt og den umiddelbare udsigelsesstruktur (jf. Figur 9), og en ny diskurs tager over:

\section{Fagdiskursen}

Esters normkilder er nemlig skønlitterære. Hendes essay er litterært inspireret, og selvom det umiddelbart virker som om det diskursive og det selvbiografiske selv smelter sammen i en personlig essaystemme, er der alligevel en afstand mellem dem som også her kan spores i tidsadverbialerne. Når det skrivende jeg således henviser til en oplevelse i skolen tidligere samme dag ("I dag, da jeg havde spisefrikvarter"), demonstreres tekstens fiktionalitet (Jacobsen et al., 2013) i kontrast 


\section{Søndagsstuen}

Jeg krammede min vinterjakke tæt ind til mig og spejdede ud over fritidshjemmets tomme gang. De hullede, râhvide vægge var dækket af hândmalede, glade ansigter, som formodentlig havde til formâl at give de unge pâ stedet et smil pâlæben. Bag døren til fællesrummet, hørte jeg stemmer, som ihærdigt snakkede og overdøvede hinanden. Med korte skridt, begav jeg mig lydløst hen over det rødbrune, støvede flisegulv. Fra den ene dag til den anden var fritidshjemmet pludselig et ubehageligt sted at være. Jeg satte mig ind pâ et af toiletterne, tog min telefon op af lommen og klikkede mig ind pâ den besked, jeg modtog i gâr aftes. “DU SKAL DØ, DIN FUCKING SKøGE" stod der. Jeg mærkede et sug i maven.

Virksomheder udnytter dem, de ældre afskyr dem og de unge er en generation af digitale indfodte pâ grund af dem. "Dem" er de sociale medier, og i nutidens samfund er vi tvunget til dagligt at bruge flere timer på digitaleplatforme for at indgâ i fællesskabet, selvom vi sandsynligvis sagtens kunne været været den virtuelle verden foruden. En stor del af vores hverdag foregâr online, og selvfølgelig understøtter de sociale medier dialog sâvel som fællesskab, men der er dog ogsâ visse ulemper ved trenden. En af dem er digital mobning. De grove beskeder er ofte meget hârdere i sproget end de ord, vi ville bruge i en samtale ansigt til ansigt, ville være, men er det os alle, der er klar over det?

Nu gâr jeg i niende klasse og siden dødstruslen i femte klasse, har jeg været meget opmærksom pâ min egen opførsel. Jeg er stadig ikke klar over hvilken af mine handlinger, der har fâet nogen til at sende mig en sâ brutal besked. I dag, da jeg havde spisefrikvarter, sad jeg alene ved mit bord i klassen med min madpakke. I modsatte hjørne af lokalet sad to piger og snakkede om en Facebook samtale, en af dem havde kørende med en dreng fra parallelklassen. Som en flue pâ væggen smuglyttede jeg diskret, men da ord som homo, luder og bitch blev læst op, fik jeg en krumme fra min rugbrødsmad galt i halsen. Jeg hostede, som var jeg rent faktisk

Figur 10. Første side af tre, Esters tekst (bilag 10).

til situationskontekstens scenarie en formiddag i eksamensperioden. Tilsvarende bevæger det diskursive selv sig væk fra det selvbiografiske både modenheds- og synsvinkelmæssigt i det afsluttende billede hvor et jeg "om søndagen" lytter til "jazz" og "kigger ned på børnene" i gården og formulerer håb for sit ufødte barn. 


\section{S. Troelsen}

Ester konstruerer sig her diskursivt som den modne (gammelkloge) og litterært dannede teenager. Den treleddede struktur som viser refleksion over fortiden og forhåbninger for fremtiden, fremviser et sekstenårigt diskursivt selv med et litterert inspireret sprog for denne modenhed. Således bryder hun essayets rammer og understreger den dobbelte semiosfære og skoleessayets karakter af imitation og iscenesættelse. Endelig bemærkes det at Esters tekst ortografisk set er stort set fejlfri og tegnsætningsmæssigt præget af en del umotiverede kommaer som kan fortolkes som en (på dette punkt mindre succesfuld) affiliering med den føromtalte korrekthedsdiskurs.

\section{Marika - kulturkompetent kommunikation}

Marika positionerer sig udpræget kommunikativt som kulturkompetent skribent der selektivt og sikkert videreformidler viden hun har researchet sig til på journalistisk vis.

\begin{tabular}{|c|c|c|c|}
\hline $\begin{array}{r}\text { Analyseper- } \\
\text { spektiv }\end{array}$ & Tekst & Fagdiskurs & Social handling \\
\hline Skriveordren & $\begin{array}{l}\text { Inspirationstekst i form af kampag- } \\
\text { nevideo i stærkt seksualiseret } \\
\text { formsprog. } \\
\text { Under filmplayeren følgende tekst: } \\
\text { Humor kan give smil på læben, } \\
\text { skabe debat, men også give anled- } \\
\text { ning til misforståelser - og dermed } \\
\text { konflikter. } \\
\text { Filmen \#BLIVMURER er et eksempel } \\
\text { på, at man anvender humor som et } \\
\text { væsentligt virkemiddel. } \\
\text { Skriveordre } \\
\text { Skriv en baggrundsartikel om dansk } \\
\text { humor. } \\
\text { Som forberedelse skal du søge op- } \\
\text { lysninger om emnet på internettet. } \\
\text { I din baggrundsartikel skal mindst } \\
\text { tre af nedenstående mellemrubrik- } \\
\text { ker indgå. Du kan selv vælge andre. } \\
\text { - Griner vi af eller med? } \\
\text { - Grin er den bedste medicin } \\
\text { - Humor misforstås ofte } \\
\text { - Hvornår er det sjovt? } \\
\text { - Vi er vilde med humor } \\
\text { - Sarkasme - den onde humor } \\
\text { - Humor eller tabu? } \\
\text { Giv din baggrundsartikel en rubrik, } \\
\text { og illustrer den med fotos, fakta- } \\
\text { bokse eller andre grafiske virkemid- } \\
\text { ler. } \\
\text { Din baggrundsartikel skal bringes i } \\
\text { en trykt avis }\end{array}$ & $\begin{array}{l}\text { Den journalisti- } \\
\text { ske genre "bag- } \\
\text { grundsartikel" } \\
\text { udpeges og led- } \\
\text { sages af journa- } \\
\text { listiske begreber } \\
\text { som rubrik, un- } \\
\text { derrubrik, fakta- } \\
\text { boks osv. }\end{array}$ & $\begin{array}{l}\text { Først aktiveres en in- } \\
\text { spirationstekst som } \\
\text { siden verbalt udpe- } \\
\text { ges som et eksempel } \\
\text { på humor som væ- } \\
\text { sentligt virkemiddel } \\
\text { hvilket står i kontrast } \\
\text { til filmens seksualise- } \\
\text { rede univers. Filmen } \\
\text { har ingen funktion } \\
\text { som andet end } \\
\text { igangsætter idet in- } \\
\text { formationer til brug } \\
\text { for artiklen skal sø- } \\
\text { ges på internettet. } \\
\text { Elevskriveren positi- } \\
\text { oneres som fiktiv } \\
\text { journalist der skriver } \\
\text { objektivt til en bred } \\
\text { målgruppe i en trykt } \\
\text { avis. }\end{array}$ \\
\hline
\end{tabular}

Figur 11. Oversigt over opgave 4 i konstellationsmodellen. 


\section{Den sociale handling}

Marika har besvaret opgave 4 (Figur 11) og skrevet en baggrundsartikel om humor (Figur 12). Også hun anvender teksttærsklerne som situations- og konfigurationsmarkør og signalerer fx herigennem forståelse af kildelistens nødvendighed i eksamensbesvarelsen som social handling, men karakter af fremmedelement i den journalistiske

Unilogin: 2

Caseskolen, 9
Dansk skriftlig fremstilling

Opgave: 4, Humor

04-05-2017

\section{Danskerne er vilde med ironi}

Humoren er, en stor del af danskernes hverdag, både på jobbet og i hjemmet. Men den såkaldte ironi er ikke altid til at forstå for alle, især hvis man ikke er vokset om med ironien som en naturlig ting.

\section{Vi er vilde med humor}

Vi danskere er efterhånden blevet ret vilde med en god joke. Det er med tiden blevet umuligt, at træede udenfor sin egen hoveddør, for den danske humor rammer os med stormstyrke. I reklamerne, i skolen og på arbejdspladsen. Ja selv $\mathrm{i}$ avisen er der tegneseriestriber, der faktisk vil gøre alt, for at fâ netop DIG til at smile. Måske endda få̉ dig til, at dreje kontorstolen 180 grader, og grine en ekstra gang, nu med kollegaen. Og hvis kollegaen er rigtig heldig, fâr han lov til, at klippe den ud, og hæenge den op på køleskabet derhjemme.

\section{Hvornâr er det sjovt?}

$\mathrm{Og}$ hvornår går det over stregen? Ironi er en stor del af den danske humor. Som integreret dansker vil man finde det naturligt med lidt ironi i hverdagen. Men ser man på den danske humor - og ironi, udefra er det med et fuldkomment andet syn. Danskerne misforstås nemt pấ international basis, der er humoren anderledes, men det er sproget også. Tonen i

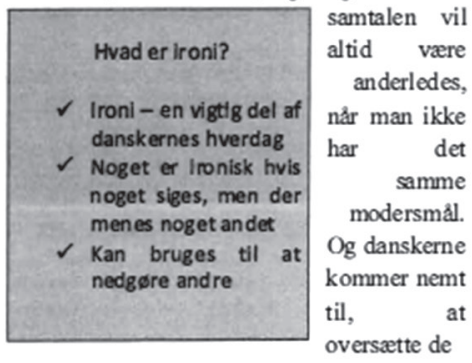

danske ord og vendinger, en smule for direkte. Så ofte vil en amerikansk mand slet ikke forstå sammenhæengen, og vil derfor hurtigt tolke situationen forkert.

Udover det, er dansk kendt for, at være et svært sprog. $\mathrm{Og}$ vi gør det bestemt ikke nemmere for nogen, når vi også bruger ironien over fầr folk vi har madt i netop samme øjeblik.

I Danmark er det normalt, at have en snak med konkurrenten. $\mathrm{Og}$ det er normalt, at gøre lidt grin med den muglige kommende situation, hvor der ikke vil være tid til hyggesnak. Det er sådan kulturen er, og der skiller vi os bestemt ud, selv inde for rimelige verdens grænser.

\section{Griner vi af eller med hinanden?}

Udover, at man skal kunne forstå meningen i ironien, skal man ogsâ kunne forstẩ năr den bliver brugt mod en. Her sammenligner Mette Møller der er forsker i retorik, os med latinamerikanerne. "Det har meget at gore med, at vi driller meget, vi stikker til hinanden. I Latinamerika er man gode til at kalde hinanden navne. Det er lidt den der uhøjtidelighed, vi tager det ikke sả tungt."

Hvis man ikke kan tage en joke eller lidt ironi, bliver man nemt stemplet som hende den kedelige. Det at have en humoristisk sans bliver en vigtigere og større værdi, og det bliver i den grad hvert sat.

\section{Store problemer bliver til smâ}

Danskerne er ogsá blevet rigtig gode til, at bruge humor og ironi omkring de problemer man nu kan have. Hovedsagligt hvis man snakker om noget der rører en meget, og det pludselig kommer lidt for tet pâ. Der er

Figur 12. Første side af to, Marikas tekst (bilag 5). 


\section{S. Troelsen}

baggrundsartikel som skal imiteres. Det gør hun ved grafisk at placere kildelisten udenfor artiklens spaltelayout, og ligesom Anna spejler hun dermed opgaveformuleringens dobbelte genreforventning i layoutet.

\section{Teksten}

Marika anvender multiple semiotiske resurser i sin multimodale tekst. Ved at indsætte sit eksamens-id som artiklens byline nederst på side 2 indikerer hun identitet mellem de to udgaver af det diskursive selv som opgaveformuleringen kræver: Marika skriver eksamensopgave og konstruerer helhjertet sig selv som fiktiv journalist. Layoutet imiterer en trykt avis - med to spalter, grafisk markering af rubrik, manchet, mellemrubrikker (hun bruger de tre opgaven kræver, og har tilføjet sin egen), faktaboks og byline. De enkelte elementer anvendes funktionelt - eksempelvis faktaboksen der på et relativt højt abstraktionsniveau definerer fænomenet ironi.

Som naturlig konsekvens af skolekonstellationen ifølge hvilken elevteksten altid er svar på en (dermed underforstået) skriveordre, er makropropositionen i elevtekster ofte underforstået (Berge, 1988, s. 90). Marikas baggrundsartikel "Danskerne er vilde med ironi" er en undtagelse, og hovedudsagnet formuleres klart i manchetten: "Humor er, (sic!) en stor del af danskernes hverdag, både på jobbet og i hjemmet. Men den såkaldte ironi er ikke altid til at forstå for alle, især hvis man ikke er vokset om (sic!) med ironien som en naturlig ting". Herefter udfoldes en række subpropositioner, omtrent svarende til de fire mellemrubrikker. Artiklen er således tydeligt vinklet og følger det journalistiske princip om at bringe det væsentligste først efterfulgt af uddybende eksempler.

Stilistisk mimes journalistikkens sprog med korte perioder, lav hypotaksegrad og syntaktisk bagvægt. Relationen mellem afsender og adressat markeres diskursivt i dels et "vi" der forener de to i fælles forståelse af den danske ironi, dels en traditionel informationsstruktur hvor artiklens afsender videreformidler viden til en modtager som deiktisk repræsenteres ved et "DIG" i versaler accentuerende læserens andel i den ironiske kultur. Sproget er varieret med fornemmelse for semantiske nuanceforskelle - fx mellem ironi og sarkasme - og få ortografiske fejl af overvejende semantisk karakter. ${ }^{21}$ Også Marika bestræber sig på at anvende kommaet som tegn, men viser - som de fleste elever i materialet - begrænset forståelse af dets funktion.

\section{Fagdiskursen}

Marikas tekst er den i intensivudvalget som mest overbevisende imiterer skriveordrens krævede genre. Således tager hun skriveordrens fiktive situationskontekst for pålydende og konstruerer et autorialt skriverselv der uden forbehold indtager rollen som journalistisk, kommunikativ formidler af viden til et bredt publikum. Normkilden er professionel journalistik, og gennem søgning på internettet performer hun den journalistiske arbejdsform med research, vinkling og formidling så autentisk som det nu lader sig gøre i eksamensskrivningens situationskontekst, og udfolder den

\footnotetext{
${ }^{21}$ Se bilag 11.
} 
journalistiske diskurs så eksamenssemiosfæren kun spores i teksttærsklerne og den afsluttende byline som er identisk med hendes eksamens-id. ${ }^{22}$

\section{Intensivudvalgets tegning af tekstkulturen}

De ovenfor analyserede elevtekster bedømmes af censor med karaktererne 02 (Emre), 7 (Anna og Marika) og 12 (Ester) og eksemplificerer således tekstkulturens nedre grænse, gennemsnitlige niveau og fulde realisering. Spørgsmålet er om der kan iagttages fællestræk i tekster med samme karakter? Med til denne diskussion hører også de øvrige tekster i intensivudvalget som analyseres kortfattet skematisk nedenfor.

\begin{tabular}{|c|c|c|c|}
\hline $\begin{array}{c}\text { Placering i } \\
\text { tekstkulturen }\end{array}$ & Tekst & Fagdiskurs & Social handling \\
\hline $\begin{array}{l}\text { Tekstkulturens nedre } \\
\text { grcanse } \\
\text { (karakteren 02) } \\
\\
\text { Victor, Lasse, Patrick } \\
\text { og Emre }\end{array}$ & $\begin{array}{l}\text { Tre tekster besvarer essayopgaven, men er } \\
\text { meget forskellige. Emre skriver fiktiv blog. } \\
\text { Victor: } 1 \frac{1}{2} \text { side uden afsnit, svagt disponeret, } \\
\text { med sparsom tegnscetning og sprog der } \\
\text { bryder sammen - morfologisk og syntaktisk. } \\
\text { Lasse: } \% \text { side, sprogligt ncesten fejlfri, } \\
\text { genremcessigt sagsformidlende prosa. } \\
\text { Patrick: } 1 \text { side, rodet layout, kludetceppe af } \\
\text { statistiske fakta og kontroversielle holdninger. } \\
\text { Emre: } 11 \% 2 \text { sides verbaltekst. Se analysen. } \\
\text { Fœelles: Svag konfiguration. Victor og Lasse } \\
\text { anvender fx begge opgaveoverskriften som } \\
\text { titel. Emre mangler teksttcerskler. }\end{array}$ & $\begin{array}{l}\text { Tilfaldige normkilder. } \\
\text { Få modaliteter - kun verbaltekst } \\
\text { og ureflekteret layout (Emre skiller } \\
\text { sig lidt ud). } \\
\text { Svag autorial positionering. }\end{array}$ & $\begin{array}{l}\text { Elevskriverne } \\
\text { positionerer sig svagt i } \\
\text { forhold fil } \\
\text { eksamensskrivningens } \\
\text { dobbelte semiosfarre } \\
\text { Elevskriverne } \\
\text { diskursiverer } \\
\text { uvidenhed på flere } \\
\text { planer (fx om genre, } \\
\text { disponering, sprog } \\
\text { og/eller } \\
\text { situationskontekst og } \\
\text { en skjult norm om } \\
\text { tekstloengde) }\end{array}$ \\
\hline $\begin{array}{l}\text { Tekstkulturens } \\
\text { gennemsnitlige } \\
\text { niveau } \\
\text { (karakteren 7) } \\
\text { Veronica, lda, Anna } \\
\text { og Marika }\end{array}$ & $\begin{array}{l}\text { Veronica: Opgave 3: Diskuterende } \\
\text { kommentar til en klumme, som hun } \\
\text { positionerer sig i opposition til. } \\
\text { Ida: Opgave 1: Essay indledt med billedfrise } \\
\text { og udspœendt mellem det personlige og det } \\
\text { generelle som munder ud i en opfordring til } \\
\text { løsning. } \\
\text { Anna og Marika: Se analyserne. } \\
\text { Fœelles: Potenseret multimodalt udtryk og } \\
\text { anvendelse af multiple semiotiske resurser. }\end{array}$ & $\begin{array}{l}\text { Varierede normkilder (skoleessay, } \\
\text { blog, journalistik). } \\
\text { Multimodalitet. } \\
\text { Veronica og Ida positionerer sig } \\
\text { autorialt som unge piger, der } \\
\text { skriver om personlige holdninger } \\
\text { og erforinger til en voksen. } \\
\text { Marika og Anna affilierer sig med } \\
\text { den diskurs som skriveordren } \\
\text { fordrer, og positionerer sig fiktivt } \\
\text { som henholdsvis kyndig blogger } \\
\text { og kompetent journalist. }\end{array}$ & $\begin{array}{l}\text { Elevskniverne } \\
\text { positionerer sig } \\
\text { reflekteret eller intuitivt } \\
\text { som indforståede med } \\
\text { opgaveformuleringens } \\
\text { eksplicitte krav } \\
\text { Elevskriverne } \\
\text { diskursiverer viden om } \\
\text { de eksplicitte krav og } \\
\text { den faglige diskurs } \\
\text { som skriveordren } \\
\text { fordrer. }\end{array}$ \\
\hline $\begin{array}{l}\text { Tekstkulturens fulde } \\
\text { realisering } \\
\text { (karakteren 12) } \\
\text { Asta, Emma. Samira } \\
\text { og Ester }\end{array}$ & $\begin{array}{l}\text { Alle tekster besvarer essayopgaven. } \\
\text { Asta: Genremcessig inkarnation af skoleessay } \\
\text { der lidt snusfornuftigt udfolder synspunkter } \\
\text { med udgangspunkt i afsenderens } \\
\text { erfaringsverden rettet mod voksen adressat. } \\
\text { Emma: Formbevidst og reflekteret udfoldelse } \\
\text { af en erkendelsesproces hvor det diskursive } \\
\text { selv skriver sig frem til en beslutning om at } \\
\text { gribe ind frem for at lade mobning passere. } \\
\text { Samira: Sprogligt risikovillig (fra det virtuose til } \\
\text { det usikre) undersøgelse i dialog med en } \\
\text { indskreven adressat - kompositorisk } \\
\text { indrammet af "Nu er det nok!" og "Synes du } \\
\text { ikke?" } \\
\text { Ester: Se analysen. } \\
\text { Fœelles: Littercert inspireret sprog. }\end{array}$ & $\begin{array}{l}\text { Littercere normkilder. Det } \\
\text { kanoniske skoleessay med } \\
\text { littercare stiltrcak. } \\
\text { Få modaliteter. } \\
\text { Emma har en eksplicit normkilde i } \\
\text { form af reference til en } \\
\text { genreplakat. } \\
\text { Autorial positionering som modne, } \\
\text { littercert dannede teenagere. } \\
\text { Elevskriverne skriver i princippet } \\
\text { som sig selv men iscenescetter sig } \\
\text { littercert gennem littercert sprog. }\end{array}$ & $\begin{array}{l}\text { Positionerer sig som } \\
\text { intuitivt vidende om } \\
\text { skolekontekstens } \\
\text { tekstkultur } \\
\text { Elevskriverne } \\
\text { diskursiverer kompleks } \\
\text { viden - fagligt og i } \\
\text { forhold til såvel de } \\
\text { eksplicitte krav som } \\
\text { den underforstc̊ede } \\
\text { norm om liftercer } \\
\text { toning. }\end{array}$ \\
\hline
\end{tabular}

Figur 13. Oversigt over intensivudvalgets tekster analyseret i konstellationsmodellens tre perspektiver.

${ }^{22}$ Selv Marikas armlægning med de drilske kommaer som vidner om en vis affiliering med føromtalte korrekthedsdiskurs, deler hun med professionelle journalister selv om dette næppe er bevidst. 


\section{S. Troelsen}

Tydelige sammenhænge mellem specifikke teksttræk og graden af anerkendelse i tekstkulturen tegner sig ikke - men enkelte tendenser træder frem:

- Tekstlcengde ser ud til at have betydning for placeringen i tekstkulturens kontinuum. Alt andet lige får tekster på én side eller derunder en lavere karakter mens længere tekst tilsyneladende kan opveje andre mangler. ${ }^{23}$

- Visse normkilder anerkendes frem for andre. Multimodal kreativitet belønnes ikke nævneværdigt. Således viser enkeltelevers omhyggelige investering i andre semiotiske resurser end verbaltekst elevtekstnormer der adskiller sig fra censors. Endvidere privilegeres skønlitterære normkilder og litterært inspireret, blomstrende sprog frem for rendyrket sagprosa og stilistisk orientering mod journalistikken. Noget klart mønster i forhold til en sproglig korrekthedsdiskurs tegner sig ikke. En næsten fejlfri tekst anerkendes kun netop i tekstkulturen mens en forholdsvis fejlbehæftet får topkarakter. ${ }^{24}$

- Elevskrivernes forståelse af genren eksamensskrivning som dobbeltkommunikation (Berge, 1988, p. 77) ser ud til at spille en rolle.

\section{Sammenfatning og diskussion}

Der er noget udpræget performativt ved at skrive eksamenstekst: Det drejer sig i mindre grad om at skrive om noget end om at demonstrere kompetence med selve kompetencen som det "noget" (jf. Berge, 2012, s. 85) som er henvendelsens egentlige referent. Dette finder jeg i nogen grad underbelyst i eksisterende forskning. Selvom mange påpeger skoletekstens dobbelte intentionalitet (Berge, 1988) og det fiktive element $\mathrm{i}$ at skrive i genrer som ikke modsvarer et udtryksbehov for eleverne (Karlsson, 1997), bliver det ofte ved konstateringen. Det egentlige skriveformål - at bestå eksamen - sættes i parentes: "Vi ser selvsagt bort fra det trivielle - men selvsagt ikke uvesentlige - forholdet at dette er en skriveprøve og at den som leser, er en sensor som skal klassifisere prestasjonen i karakterbaserte ferdighetsnivåer”, hedder det fx om studiet af kommunikationskontrakten i norske afgangsprøver (Berge, 2005b, s. 22, min fremhævning). Ved (med selvfølgelighed) at vende opmærksomheden bort fra det selvfølgelige ignoreres den egentlige exigence, forstået nyretorisk som det problem der påkalder sig løsning gennem retorisk handling (Bitzer, 1968; Miller, 2015). Dermed sløres også den reelle adressat som netop i high-stakes-konteksten træder frem som definerende for eksamensgenren som social action - eller i FoS-terminologi: skrivehændelsen som social handling - og det bliver utydeligt at det egentlig formål med eksamensskrivningen er at konstruere sig diskursivt som en "kind of person" som kan anerkendes som deltager i tekstkulturen. At gøre dette forudsætter

\footnotetext{
${ }^{23}$ Når Lasses ortografisk fejlfrie besvarelse kun netop anerkendes som tekst, kan det således skyldes at den er casens korteste, mens Victors sprogligt uforståelige tekst opnår samme anerkendelse qua sin længde.

${ }^{24}$ Henholdsvis Lasses og Samiras tekster.
} 
opmærksomhed på såvel skriveordrens eksplicitte genrekrav som eksamenskontekstens implicitte fordringer, og da dette ikke kommunikeres eksplicit i skriveordren og dens paratekster (Troelsen, 2018), må eleven selv slutte sig hertil på baggrund af erfaringer med blandt andet skolekulturelle skrivepraktikker og de normkilder disse aktualiserer.

Ved at betragte elevteksterne som diskursive realiseringer af den retoriske handling "at skrive eksamenstekst" har jeg ovenfor forsøgt via abduktion at portrættere fire tilgange til håndtering af skriveopgavens flertydighed gennem skrift: strategisk kreativitet, umiddelbar narration, intuitiv iscenescettelse og kulturkompetent kommunikation. Disse skal ikke forstås som generelle kategorier, men som eksempler på fire elevers håndtering af den retoriske situations spændingsfelt mellem flertydighed og (præstations- og tids-)pres. De rummer alle en dobbelthed som i nogle tilfælde falder ud som dissonans eller ambivalens. Og de har fællestræk på tværs selvom de også er udtryk for meget forskellige strategier.

Ester og Emre er fælles om det umiddelbare og intuitive som for Emre medfører brud med skriveordrens krav mens det for Ester er uproblematisk. Det frirum som består i at hun ikke skal fordoble sin diskursive positionering, søge på internettet eller have opmærksomhed på tekstens layout for at indfri kravene, sætter hende fri til at arbejde mere kommunikativt og rituelt. "En deltaker har (...) inkorporert de relevante tekstnormene i kulturkonteksten" (Berge, 2005b, s. 16). Esters essay viser en intuitiv forståelse af ikke blot essayet som genre, men også det "som inom skolan som institution förstås som en essä" (Borgström 2010, s. 140, min fremhævning), og som i dette tilfælde endda kan rumme en ikke ubetydelig fiktionalisering uden at komme i konflikt med genreforventningen. Det er denne sammensatte tekstnorm hun har inkorporeret og mestrer intuitivt og suverænt. Modsat går Emres umiddelbare identifikation med fabulerende ungdomsfiktion skævt af den retoriske situation, og det lykkes ham kun lige at skrive sig ind i tekstkulturen. "In the modern world, achieved D-Identities do not enjoy recognition as a matter of course. Individuals must win recognition for them through exchange with others, and such an attempt can fail" (Gee, 2000). Emre fejler fordi han fortolker Diskursen (med stort D) forkert (Gee, 2000) når han omgås skriveordren selektivt og ignorerer både eksplicitte og implicitte krav. Det lykkes ham ikke at blive deltager, at konstruere sig diskursivt som den "kind of person" der er god til at skrive eksamenstekst. Derimod kommer hans diskursive selv til at stå i opposition til autoriteter og institutioner - både på tekstens tematiske plan og i den retoriske handling.

Fælles for Anna og Marika er omvendt en mere refleksiv og strategisk adressering af skriveordrens krav og den fordoblede semiosfære. Begge udfolder multimodalt en avanceret håndtering af det sammensatte skriveformål og imiterer overbevisende henholdsvis bloggenren og baggrundsartiklen fra makro- til mikroniveau. At de kun vurderes som gennemsnitlige i tekstkulturen, kalder - sammen med de øvrige fund på kvalitative undersøgelser af censorernes tekstnormer og videre undersøgelse af mulige sammenhænge mellem karakterer og bestemte opgavetyper. 
Tak

Tak til Nikolaj Elf og Kjell Lars Berge for klogt og engageret med- og modspil under arbejdet med denne artikel.

\section{Forfatterbiografi}

Solveig Troelsen er lektor ved VIA University College, Læreruddannelsen i Århus, og ph.d.-stipendiat ved Institut for Kulturvidenskaber, Syddansk Universitet.

\section{Referencer}

Bakhtin, M. M. (1986). The Problem of Speech Genres. I C. Emerson \& M. Holquist (Red.), Speech genres and other late essays Austin: University of Texas Press.

Barton, D. (1998). Local literacies : reading and writing in one community. London: Routledge.

Beck, S. W. \& Jeffery, J. V. (2007). Genres of high-stakes writing assessments and the construct of writing competence. Assessing Writing, 12(1), 60-79. Retrieved from http://www.sciencedirect.com/science/article/ pii/S1075293507000220

Berge, K. L. (1988). Skolestilen som sjanger. Med påtvungen penn: Oslo: LNU/Cappelen.

Berge, K. L. (1996). Norsksensorenes tekstnormer og doxa: en kultursemiotisk og sosiotekstologisk analyse: Institutt for anvendt språkvitenskap det historisk-filosofiske fakultet Norges teknisk-naturvitenskapelige universitet Trondheim.

Berge, K. L. (2005a). Skriveprøvenes pålitelighet. I K. Berge, L. Evensen, F. Hertzberg \& W. Vagle (Red.), Ungdommers skrivekompetanse Bind I.

Berge, K. L. (2005b). Tekstkulturer og tekstkvaliteter. I K. Berge, L. Evensen, F. Hertzberg \& W. Vagle (Red.), Ungdommers skrivekompetanse Bind II.

Berge, K. L. (2008). Teksten. In K. Asdal, K. L. Berge, K. Gammelgaard, T. R. Gundersen, H. Jordheim, T. Rem \& J. L. Tønnesson (Red.), Tekst og historie. A lese tekster historisk. Oslo: Universitetsforlaget (s. 175-220). Oslo: Universitetsforlaget.

Berge, K. L. (2012). Om forskjellene mellom systemisk-funksjonell lingvistikk og tekstvitenskap. I S. Matre, D. K. Sjøhelle \& R. Solheim (Red.), Teorier om tekst i møte med skolens lese-og skrivepraksiser (s. 72-90). Oslo: Universitetsforlaget.

Berge, K. L., Evensen, L. S., Hertzberg, F. \& Vagle, W. (2005). Ungdommers skrivekompetanse (Bind I E II). Oslo: Universitetsforlaget.

Berge, K. L. \& Ledin, P. (2001). Perspektiv på genre. Rhetorica scandinavica, 18(6), 4-16.

Bitzer, L. F. (1968). The Rhetorical Situation. Philosophy E Rhetoric, 1(1), 1-14. Retrieved from https://www. statsbiblioteket.dk/au/\#/search?query=recordID\%3A\%22summon_FETCH-LOGICAL-1793-cc24abb3 61561e81fb730ca1d82cc82d789f7241665af6d9432b6a7e3411fab3\%22

Bråten, I. (2008). Læseforståelse - komponenter, vanskeligheder og tiltag. I I. Bråten (Red.), Laeseforståelse. Lesning $i$ videnssamfundet - teori og praksis (s. 11-21). Århus: Klim.

Bundsgaard, J., Buch, B. \& Fougt, S. S. (2017). De anvendte læremidlers danskfag belyst kvantitativt. I Lceremidlernes danskfag (s. 28-54): Aarhus Universitetsforlag.

Christensen, T. S., Elf, N. F. \& Krogh, E. (2014). Skrivekulturer i folkeskolens niende klasse. Odense: Syddansk Universitetsforlag.

Dolin, J., Nielsen, K. \& Rangvid, B. S. (2018). Rapport fra Følgegruppen for en bedømmer ved folkeskolens prøver. Retrieved from https:/uvm.dk/-/media/filer/uvm/udd/folke/pdf18/apr/180425-rapport-fra-foelgegruppenfor-een-bedoemmer-ved-fp.pdf?la=da

Evensen, L. \& Vagle, W. (2005). Oppgavesettene og elevenes oppgavevalg i KAL-årene. In Ungdommers skrivekompetanse. Bind I: Norsksensuren som kvalitetsvurdering, ed. K. L. Berge, L. S. Evensen, F. Hertzberg, and W. Vagle (s. 161-203).

Flyvbjerg, B. (2010). Fem misforståelser om casestudiet. In S. Brinkmann \& L. Tanggaard (Red.), Kvalitative metoder. En grundbog (s. 463-487): Hans Reitzels Forlag.

Gee, J. P. (2000). Chapter 3: Identity as an analytic lens for research in education. Review of Research in Education, 25(1), 99-125. 
Hobel, P. (2011). Skrive for at lære og løse problemer. I S. H. Klausen (Red.), På tvars af fag (s. 139-178). København: Akademisk Forlag.

Indenrigsministeriet. (1941, 10.08.2012). Bekendtgørelse om Maalet for Folkeskolens Undervisning. Lov nr. 242 af 24. maj. Retrieved from http://danmarkshistorien.dk/leksikon-og-kilder/vis/materiale/bekendtgoerelse-om-maalet-for-folkeskolens-undervisning-24-maj-1941/

Indenrigsministeriet. (1958). Lov nr. 220 af 18. juni: Bekendtgørelse af Lov om Folkeskolen. Retrieved from http://danmarkshistorien.dk/leksikon-og-kilder/vis/materiale/bekendtgoerelse-af-lov-om-folkeskolen-18juni-1958/

Ivanič, R. (1998). Writing and Identity: The discoursal construction of identity in academic writing. Amsterdam/ Philadelphia: John Benjamins Publishing.

Ivanič, R. (2012). Writing the self: the discoursal construction of identity on intersecting timescales. I S. Matre, D. K. Sjøhelle \& R. Solheim (Red.), Teorier om tekst $i$ møte med skolens lese- og skrivepraksiser. Oslo: Universitetsforlaget.

Jacobsen, L. B., Kjerkegaard, S., Kraglund, R. A., Nielsen, H. S., Reestorff, C. M. \& Stage, C. (2013). Fiktionalitet (1. udgave). Frederiksberg: Samfundslitteratur.

Jakobsen, K. S. (2016). Kreative skriveopgaver. Kreativitet i to elevers skrive- og skriverudvikling $\mathrm{i}$ fremmedsprogene. I K. S. Jakobsen \& E. Krogh (Red.), Skriverudviklinger i gymnasiet: Syddansk Universitetsforlag.

Jensen, T. B. (Red.) (1999). At tenke uden styrthjelm og kncebeskyttere : om essayet som genre og det danske essay $i$ det 20. århundrede (1. udgave). Kbh.: Dansklærerforeningen.

Jordheim, H. (2008). Sjangeren. I K. Asdal, K. L. Berge, K. Gammelgaard, T. R. Gundersen, H. Jordheim, T. Rem \& J. L. Tønnesson (Red.), Tekst og historie. A lese tekster historisk. Oslo: Universitetsforlaget (s. 175220). Oslo: Universitetsforlaget.

Karlsson, A.-M. (1997). Textnormer i och utanför skolan - att skriva insändare på riktigt och på låtsas. Svenskans beskrivning, 22.

Karlsson, A.-M. (2006). En arbetsdag $i$ skriftsamhället: ett etnografiskt perspektiv på skriftanvändning $i$ vanliga yrken: Norstedts Akademiska Förlag, Stockholm.

Krogh, E. (2014). Overgangen fra grundskole til gymnasium. En elevskrivers håndtering af skiftende skrivekulturer og positioneringer. I P. Andersson, P. Holmberg, A. Anna Lyngfelt, A. Nordenstam \& O. Widhe (Red.), Mångfaldens möjligheter: Litteratur- och språkdidaktik i Norden (s. 155-180). Göteborg: Institutionen för svenska språket, Göteborg Universitet.

Krogh, E. (2015). Faglighed og skriftlighed - teori, metode og analyseramme. I E. Krogh, T. S. Christensen \& K. S. Jakobsen (Red.), Elevskrivere i gymnasiefag. Odense: Syddansk Universitetsforlag.

Krogh, E. \& Hobel, P. (2012). "Årets bedste opgave": en analyse af en elevtekst i dens kontekst. I S. Matre, D. K. Sjøhelle \& R. Solheim (Red.), Teorier om tekst $i$ møte med skolens lese- og skrivepraksiser. Oslo: Universitetsforlaget.

Lillis, T. (2018). Evalueringsregimer i forståelsen af skrivning - og forsøg på at modstå dem. IT. S. Christensen, N. Elf, P. Hobel, A. Qvortrup \& S. Troelsen (Red.), Didaktik i udvikling (s. 281-295). Aarhus: Klim.

Miller, C. R. (2015). Genre as Social Action (1984), Revisited 30 Years Later (2014). LETRAS E LETRAS, 31(3), 56-72.

Miller, C. R. \& Shepherd, D. (2004). Blogging as social action: A genre analysis of the weblog. Into the blogosphere. Retrieved from http://hdl.handle.net/11299/172818

Otnes, H. (2013). Fiktive skriveroller og ukjente mottakere. Kontekstualisering i skriveoppgaver. I N. Askeland, E. Maagerø \& B. Aamotsbakken (Red.), Lareboka. Studier i ulike lereboktekster. Trondheim: Akademika forlag.

Otnes, H. (2015). Å invitere elever til skriving: ulike perspektiver på skriveoppgaver (H. Otnes Red.). Bergen/Oslo: Fagbokforlaget, Landslaget for norskundervisning.

Rytter, C. \& Stadelund, L. (2014). PEU DANSK 2013-Prøver, evaluering og undervisning. Retrieved from https:// www.uvm.dk/-/media/filer/uvm/udd/folke/pdf14/mar/140326-2-peu-dansk-260314-cr.pdf

Rømhild, L. P. Rammefortælling. I Gyldendal (Red.), Den Store Danske. http://denstoredanske.dk/index. php?sideId=148524. 25. oktober 2018.

Skar, G. B. (2013). Skrivbedömning och validitet: fallstudier av skrivbedömning $i$ svenskundervisning på gymnasiet. Institutionen för språkdidaktik, Stockholms universitet.

Smedegaard, A. (2016). Genrer som rammer: Et genreanalytisk studie af institutionelle skrive-og eksamenspraksisser $i$ det almene gymnasiums danskfag med afscet $i$ en diskussion af pragmatisk genreteori. Københavns Universitet, Det Humanistiske Fakultet. 


\section{S. Troelsen}

Smidt, J. (2009). Overgang. Skrivekulturer på ungdomstrinnet og i videregående skole. In O. K. Haugaløkken, L. S. Evensen, F. Hertzberg \& H. Otnes (Red.), Tekstvurdering som didaktisk utfordring (s. 63-73). Oslo: Universitetsforlaget.

STUK. (2016a). Falles mål for faget dansk. Retrieved from https://www.emu.dk/modul/dansk-fælles-mållæseplan-og-vejledning

STUK. (2016b). Vejledning til folkeskolens prøver i faget dansk - 9. klasse.

Togeby, O. (2015). Den dobbelte genreforventning. In Elevskrivere $i$ Gymnasiefag: Syddansk Universitetsforlag. Troelsen, S. (2018). En invitation man ikke kan afslå - analyse af afgangsprøven i skriftlig fremstilling med særligt fokus på skriveordren. Nordic fournal of Literacy Research, 4(1), 142-166. doi:10.23865/njlr.v4.1267

Undervisningsministeriet. (2016-17). Datavarehus Grundskolen https://uddannelsesstatistik.dk/grundskolen

Undervisningsministeriet. (maj 2017). FP9 Dansk Skriftlig Fremstilling. 


\title{
Bilag 1: Victors tekst
}

FSP 2017 skriftligt Dansk med hjælpemidler

$4 / 52017$ Caseskolen

9.

\author{
UNI-Login $\mathrm{xxx}$
}

\section{Digital mobning}

Digital mobning kan starte fordi der er en gruppe af folk der ikke kan lide dig som der har et had imod noget du har gjort eller bar hader dig som et person men det kan også være fordi du er et nemt offer som fx. du er meget følsom eller du er nemt at gøre sur eller sådan noget det er ikke noget some der er noget galt med men du kan også bare være et uheldigt offer som er at du ikke har gjort noget og er helt uskyldig men den gruppe eller person der gøre det bar keder sig så han vil drille en og det er bar uheldig. Digital mobning kan påvirke hvordan du gøre det i skolen som fx. du kan ikke koncentrer dig fordi du er konstant bange for at der er noget der vil gøre noget imod dig og har ud ikke turde at rakke din hånd på når du skal bruge hjælp eller hvis du vil svar på et spørgsmål det kan være meget svært for en fordi man er bange for at folk vil grine eller der vil mobbe dig mere hvis du svarer forkert digital mobning kan også gøre at du ikke kan føle dig sikker nogen steder fx. når du er bar ude og gå det og at man ikke får lyst til at gå i skole længer fordi man er bange for at der vil ske noget hvis du møder op og ikke et gang derhjemme kan du føle dig sikker længer nogle gang kan det også gå så langt at man får selvmordstanker men som jeg plejer at sige selvmord er en heltids løsning på et midlertidigt problem, og man måske bliver nødt til at gå til psykolog og skal til at have hjælp i en meget ung alder det kan også ændre på hvordan man bliver i fremtiden som i at man bliver et meget usikker person som der ikke er klar på noget nyt der kan også ske at man selv begynder at mobbe folk fordi at man vil få noget af alt den vrede ud og at man har ændret sig helt som en person fordi man blive mobbet, man kan også begynde at tage stoffer fordi at det får et til at tænke på noget andet og får det til at slappe af, man kan også gå helt psykisket ned fordi at man bare ikke kan slappe af og der bliver ved med at skrive og så ender det med at man får et mentalt nedbrud at man bare falder helt sammen og man føler bar hele verden rundt om en er lort og man bare vil få det hele til at stoppe at sætte en ende til det hele. Hvis man godt vil pøve at får det til at stoppe eller gøre noget der hjælper så kan man pøve at stoppe med at reagere på det det er meget svært men det er et løsning eller som man vil nok være det bedst er at får noget hjælp fra venner familie eller lærerne fra skolen pøve at får fat i nogle der vil bakke dig op som du kan stole på fx. din best ven eller din store bor nogle som du kan fortælle alt og som der forstå dig det hjælper altid at få snakket ud og ting man kan også søge hjælp ved en psykolog det vil noget ikke være mit personlige valg men folk er anderledes og fordi der kan komme et punkt hvor ens venner ikke kan hjælpe mere og hvor en psykolog vil nok være en god ide men jeg vil nok vælge min venner først fordi der er nogle som du kan bare være dig selv ved. 


\section{S. Troelsen}

FSP 2017 skriftligt Dansk med hjælpemidler

$4 / 52017$ Caseskolen

9.

UNI-Login 6

Der er ikke så meget man kan selv gøre imod det så det bedst vil være at søge efter hjælp fra nogle som du føler tryk ved. man kan ikke som sådan stoppe Digital mobning det er mere hvordan den person der gøre det det kan være fordi han har selv har haft et dårligt liv og han vil få sin vrede ud på nogle andre så det kan være der for han mobber og at han ikke får den hjælp han har brug for eller det kan være fordi han bar vil se sej ud foran sine venner og spille smart og vise at det er ham der styrer det her sted men for at være ærlig er det nok sej at vise and man kan rejse sig op i sige imod den dude der mobber og stop ham og at hjælpe den person der bliver mobbet der er ikke nogen bedre følelse for den der bliver mobbet end at folk står op for ham og man bevise også til ham at man er hans rigtige venner hvis man bakker ham op fx. hvis man ved hvem der gøre alt det imod ham så sige det til nogle der kan stoppe det eller bar hjælp den person der har bruge for det.

Kilder:

clioonline.dk

Youtube.com 


\section{Bilag 2: Emres tekst}

\section{Cyklen}

Solen skinner, det blæser dog lidt. Kasper er i gang med at snakke med hans mor angående sejlturen til Ærøskøbing, han er mors dreng. Klokken er 16:58, Kasper, Karen, Villy og jeg venter på Morten, som skal med hen til vores efterskole. Så kommer han kraftedme siddende på en cykel, og den må ikke med ombord. "Hvad så drenge" siger han, vi andre kan ikke lade være med at grine, "amen din kraftidiot, har du ikke lige købt den cykel” siger Villy, "Jo, og hvad så? ” siger han så, " ha ha ha, du må ikke tage den med ombord, der er nye regler” siger Karen, vi alle griner undtagen Morten som kigger fornærmet på os “oh fuck, hvad fanden gøre jeg nu! ” vi stopper med at grine, vi kan se at han bliver en lille smule ked af det, fordi cyklen er splinter ny. Vi får så den ide, at vi smugler cyklen ind uden nogen ser det. Klokken er 16:03, og vi skal ombord, færgen sejler om to minutter, og den cykel skal bare ind. Der er to indgange, en til passagerne og en til personale. Planen er at Morten og Villy tager personale døren og vi tager den anden, mens vi distrahere personalerne ombord. Kasper, Karen og jeg går ind, vi sætter os, og nu venter vi bare på Villy og Morten. "Fuck, hvad med hvis de er blevet taget! " siger Karen, "så længe Villy er der, sker der ikke noget”. Villy har altid været "Einstein” i gruppen. Nu kommer de, de kommer grinende og glad, vi alle begynder med næsten at dø af grin, og vi har ikke en ide om hvad vi griner af.

\section{Smøgen}

Nu sidder vi og hygger, vi har købt nogle snacks og en sixpack af kolde red Bulls. Det tager fem og halvfjerds minutter at ankomme til Ærøskøbing, så vi spilder tiden ved at spille kort og snakke sammen. Karen kan ikke lige at sejle, han bliver søsyg, og ender med at kaste hans mors gode lasagne op gentagne gange, mens vi andre gemmer os og griner lidt, men det ligger han selvfølgelig mærke til, og kaster op over Kasper, vi andre griner højlydt, men Morten bliver meget sur og fornærmet "Hvad fuck har du gang i, Karen. Min mor har lige købt denne her trøje, din idiot! " "Du kunne da bare lade være med at grine" siger Karen, mens dig bliver spyttet hans mors lasagne ud. "Ej, nu kan jeg ikke mere, jeg skal fandme have en smøg" siger Villy, "Så gå dog ud og tag en, der er sgu ingen der holder dig”, "ud? haha, jeg tænder den her min ven”, Selvom Villy var den klogeste, kan han engang imellem godt være med til lidt drengerøve. Han tager hans Marlboro gold pakke frem, tager en smøg og tænder den. De andre passagerer kigger irriteret og ondt på os, men de ved hvem vi er, de ved at hver sejltur med Ærøskøbing færgen, ikke skal sejle uden lidt drengerøve. Vi andre fniser og Villy nyder bare sin smøg, men nu kommer personalet fandme. Villy skynder sig at slukke den, "oh nej drenge, det er ham fra sidst" siger jeg, "er det nu jer igen? sig mig hvad fanden har i gang i! i skal sguda ikke tænde en smøg herinde! " vi stirre på hinanden, men siger intet, "en fejl mere, og jeg kaster jer fandme ud af færgen, så må i svømme hjem! ”, vi holder bare kæft, for den mand kan fandme godt finde på det. Så Villy gik bare ud og røg, mens vi andre spiller kort, for nu er der en halv time tilbage. 


\section{S. Troelsen}

\section{Ankommet}

Nu er der cirka fem minutter før vi ankommer til Ærøskøbing. Vi orker ikke at vente på køen, når vi skal ud, så vi går bare hen til døren nu. Og nu er vi ankommet. Vi skal tage en bus hen til efterskolen om cirka tyve minutter. Vi ved ikke rigtigt hvad vi skal nu, vi keder os. Vi tager på tanken og køber lidt mad, da vi er ret sultne efter sejlturen. Jeg køber tre Donuts, og de andre køber pizza slice, nu sidder vi henne ved havnen og spiser. Det sgu hygge, vi nyder solnedgangen, inden vi skal hen til efterskolen. Karen, Morten, Villy og Kasper er mine bedste venner, jeg har det altid godt i deres selskab. Men nu kommer bussen og vi skal gå. I bussen ser vi vores kammerater fra skolen, vi snakker lidt med dem og senere sidder vi ned og spiller kort igen. "ærligt, jeg orker virkelig ikke skole” siger jeg "Det er der ingen der gøre Chris" siger Villy. Nu er vi ankommet, og bare ved at kigge på efterskolen giver mig negative tanker, jeg har virkelig ikke lyst. Vi går ind, og går imod vores værelser, jeg deler værelse med Villy. Vi har massere af plakater af rapperne fra 8oerne, Tupac, N.W.A og Biggi. Klokken er cirka seks, og vi skal lave tysk stilen til i morgen, men det klare Villy for mig, så nu skal jeg bare se en film og sove. 


\section{Bilag 3: Annas tekst}

Unilogin: $\mathrm{xxx}$

Caseskolen

\section{AER $\varnothing$ EFTERSKOLE}

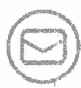

FRØ@EFTERSKOLE.DK

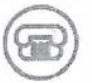

62521724

Tranderupgade 59

5970 Arøskøbing

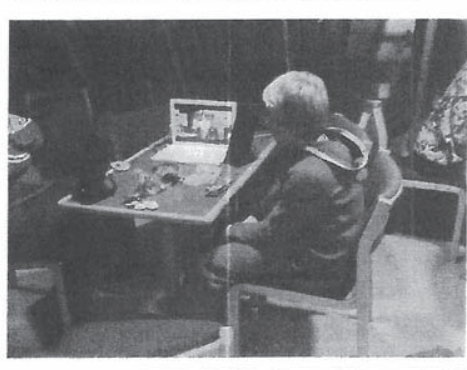

Tids udtrækning. :
Dansk skriftlig fremstilling

$05-04-2017$

2 Strandet mellem Svendborg og $\not$ Er $\varnothing$

\section{ELEV - INDLAG}

27/11 - 2011 KI. 17.04

\section{En mærkelige rumlen og knap så gode nyheder}

Jeg sidder i færgen på vej til efterskolen efter en hjemmeweekend, sammen med 4 andre tøser. Vi spiller kort, spiser lidt chips og hygger. Pludselig kommer der en mærkelig rumlen fra venstre side af båden. Vi kan ikke lige finde ud af hvad det er der forsager lyden. Jeg kigger ud af vinduet, og kan jeg se at vi ikke sejler. Det virker lidt mærkeligt fordi vi er ikke tæt på nogen havn og vi har kun sejlet i $45 \mathrm{~min}$.

Lidt efter lidt finder folk ud af at vi ikke sejler, og man kan se på folk at der er ved at skabe sig en lille smule panik. Mig og de fire andre tøser forholder os nogenlunde i ro, men Ninna kan ikke lade være med at tænke på hvad der kunne være sket, hun plaprer løs om alt fra Titanic til olieudslip og at vi muligvis skal $d \varnothing$.

Efter noget tid kommer der en meget venlig kvinde ind som arbejder på båden. Hun fortæller ud i rummet: "Vi er desværre kommet i den uheldige situation, at vi ikke kan sejle lige forløbelig. Vi holder nu stille pga. en storm, som har forsaget at der nogen steder er meget lavvandet. Så lige nu sidder vi fast i en sand banke som vi ikke kan komme fri af. Alt er under kontrol! Hvis der er nogen der har nogle spørgsmål må i meget gerne henvende jer". Alle ånder lettet op, der begynder at danne sig en smule små snak på kryds og tværs af passagerene, alle de små børn leger videre og de gamle læser deres avis.

Mig og Ninna beslutter os for at gå op til den venlige kvinde for at spørge om, hvornår de regnede med at være på ÆErø. Efter godt 5 min for vi øje på hende, hun står og snakker med en ældre mand. Vi går hen mod hende. Hende og manden lige er blevet færdig med at snakke så hund vender sig mod os. "Hvad kan jeg gøre for piger?" siger hun smilende, "Vi ville bare lige høre hvornår i regner med at vi kunne være på $A$ rø?" svare Ninna. "Det er meget svært at sige" siger hun og kigger på sit ur, "Vi regner med at der kommer en slæbebåd om et par timer, og så må vi se til den tid" Vi takker i og går hen til vores pladser igen.

Fortsættelse følger.

Hilsen A.K 
Unilogin 7

Caseskolen

\section{AER $\varnothing$ \\ EFTERSKOLE}

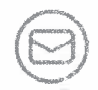

FRØ@EFTERSKOLE.DK

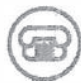

62521724

Tranderupgade 59

5970 Frøskøbing

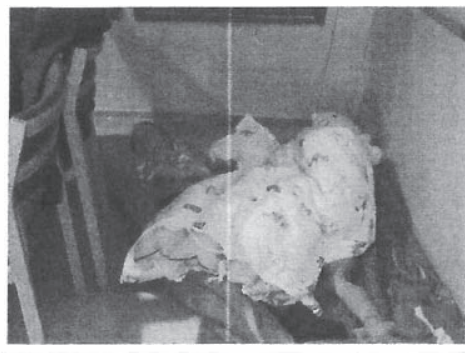

En knap så god seng som den der hjemme. :
Dansk skriftlig fremstilling

$05-04-2017$

2 Strandet mellem Svendborg og AEr $\varnothing$

9.

\section{ELEV - INDLAGG}

27/11-2011 Kl. 20.16

\section{En hyggelig aften og trætte passagerer}

Klokken har nu passered otte, vi sidder og spiser slik og ser film på Frejas computer. Færgen havde nogle frosne fiskefileter vi fik til aftensmad, det var ikke det bedste men det kunne spises. Det er virkelig utroligt hvad personalet laver, de finder tæpper, mad og drikkevarer og varder os bare op. De er virkelig også søde mennesker.

Omkring kl. 19.30 havde slæbebåden været her. En mandelig ansat kom og fortalte, at det desværre ikke var lykkedes, for slæbebåden at få færgen fri pga. vejret og at vandet ikke var steget, men at de ville prøve igen kl. 3 i nat. Vi har også ringet til efterskolen for at sige at vi ikke kunne nå frem i aften, men måske ville vi ankomme i morgen ved middagstid.

De andre passagerer ser ud til at hygge sig, nogle af de små børn ligger og sover på gulvet (kan ses på billedet til venstre) og andre har en bog med som de sidder og læser i. Før der var aftensmad spillede vi "500" med et ældre ægte par, det var vildt hyggeligt. Der var også et andet bord med nogle voksne der havde spillet Bezzerwizzer. Ninna prøver lige nu at sove, hun ligger med hovedet på mit skød og med sit tørklæde over sig. Tror gerne jeg snart vil sove, føler mig rimelig udmattet efter sådan en omgang.

Filmen er færdig, de fleste passagerer ligger og sover, det samme gør der andre tøser. Jeg var åbenbart den eneste der kunne holde mig vågen til filmens ende. Jeg får forsigtig flyttet Ninna fra mit skød, går hurtigt på toilet og finder der efter nogle tæpper til mig og de andre tøser.

Der kommer en indberetning i morgen, sov godt!

Hilsen A.K 
Unilogin 7

Caseskolen

\section{AER $\varnothing$ \\ EFTERSKOLE}

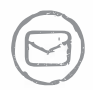

ÆRØ@EFTERSKOLE.DK

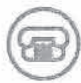

62521724

Tranderupgade 59

5970 Ærøskøbing

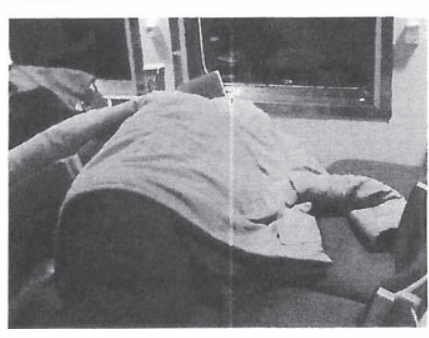

Når man ikke har andet at give sig til end at sove.
Dansk skriftlig fremstilling

$05-04-2017$

2 Strandet mellem Svendborg og \& Erø

9.

\section{ELEV - INDLAEG}

28/11 - 2011 KI. 09.00

\section{Kurs mod Arø og efterskolen}

Alle passagerer er nu vågne, den søde besætning har lavet boller til os her til morgen, de smager vildt godt. Man kan godt se på folk nu at de gerne vil hjem og at de nok ikke har fået den bedste nattesøvn. Jeg har selv sovet udmærket, vågnet nogle gange med det var mest det. Den venlige Kvindelige besætningsmedlem kommer ind $\mathrm{i}$ opholdstuen, og man kan se på hende at hun skal fortælle noget, hun rømmer "Som i nok har lagt mærke til sejler vi stadig ikke, det lykkedes ikke at få færgen fri kl. 3 i nat. Men jeg tror vi har heldet med os i dag, vandet er steget en smule så om nogle timer, eller mindre kommer der en slæbebåd og prøver at få os fri igen.

Stemningen er faldet en del siden i går aftes, folk er trætte og ikke særlig snaksaglige. Det er også forståligt vi har næsten været her i 14 timer. Jeg vil egentlig også gerne bare hjem, det har været en god oplevelse, men nu må den gerne slutte, og jeg tror de andre tøser er enige.

Jeg sidder i vindueskarmen og kigger ud, solen skinner, men der kommet lidt is på ruden så det er nok også rigtig koldt. Lidt ude i det fjerne kan jeg se en båd, og jeg tror den er på vej mod os, jeg beder til at det er slæbebåd. Det var det sku. Færgen bliver hægtet fast, alle venter i spænding. Der lyder nogle rumlende lyde, det hele ryster. ENDELIG!!! Vi er fri, alle jubler selv de ansatte. Endelig er vi på vej mod ÆErø og efterskolen. Jeg glæder mig vildt meget til at komme på land og hen på efterskolen!

En ansat kommer ind og siger at vi nu er sejlende og at vi nok er i havn om en times tid.

Vi ses

Knus A.K 


\section{S. Troelsen}

Unilogin 7

Dansk skriftlig fremstilling

$05-04-2017$

2 Strandet mellem Svendborg og $\mathcal{A r} \varnothing$

9.

Caseskolen

Kildeliste:

Larsen, Vestergaard Jesper: " ÆErø-færge stødt på grunde med 148 ombord", BT

(Besøgt: 4. Maj 2017, oprettet: 27.Nov. 2011)

http://www.bt.dk/danmark/aeroe-faerge-stoedt-paa-grund-med-148-ombord

Clausen, Labarca Laura: " Uvist hvornår den strandede AErøfærge kommer fri. 148 har overnattet på færgen", Berlingske

(Besøgt: 4. Maj. 2017, Oprettet 28. Nov. 2011)

https://www.b.dk/nationalt/strandet-faerge-sidder-fast-med-148-ombord

Thomsen, Søgaard Ulla: "AErø-færgen er nu trukket fri" inkl. Billeder, DR.

(Besøgt: 4. maj. 2017, Oprettet: 28. Nov. 2011)

http://www.dr.dk/ligetil/indland/aeroe-faergen-er-nu-trukket-fri 


\section{Bilag 4: Idas tekst}

Uni-Login: $\mathrm{xxx}$

Klasse: 9

\section{Digital mobning}

Mobningen er flyttet fra skolegården til internettet
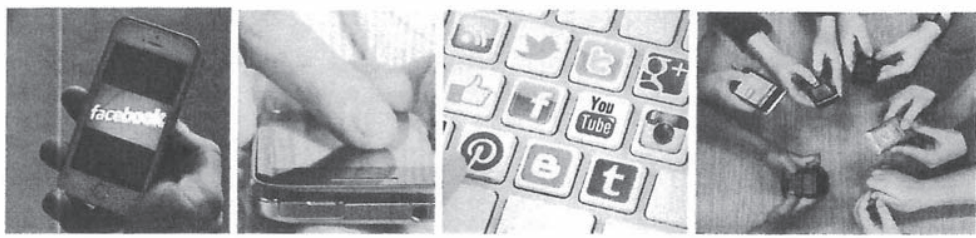

"Pling". En, to, tre beskeder fra veninden eller fra den dreng man bliver blød i knæene af at tænke på. Det er meget normalt at få tyve til tredive beskeder eller meldinger, og endnu mere normalt at kigge på mobilen eller computeren flere gange på en dag. Følelsen af spænding når der lyder et "PLING" fra bukselommen, hvem søren skriver og hvad mon det omhandler. Desværre er det ikke altid positive meldinger der popper op på skærmen. De sociale medier er blevet et grimt værktøj for unge, her er der stort set ikke en grænse for hvilke beskeder der sendes. Mobningen fra skolegården er nu flyttet til telefonen og computeren. Det er ligefør at digital mobning er grimmere end fysisk mobning. Når der fysisk mobbes er det uden tvivl frygteligt, men der er en befrielse når dagen er slut. Hvorimod net-mobningen fortsætter derhjemme, der kan der poppe en besked op hvert sekund.

Net-mobning er ikke kun at modtage grimme beskeder, men også at få misbrugt eller offentliggjort nogle private ting, som et billed eller nogle beskeder.

Der mobbes ikke kun på de sociale medier, men også på de offentlige internet-børnespil, er børn ufattelige stride mod hinanden. Da jeg var 10 år gammel, der spillede mine klassekammerater og jeg et offentligt børnespil ved navn "Moviestarplanet". Det handlede om at lave sin egen moviestar, som kunne få venner, købe tøj, dyr, tjene penge, lave værelser og chatte med andre moviestars. Vi havde det alle super sjovt og det var så hyggeligt at spille det sammen. Nu er jeg 16 år og jeg var inde på siden forleden med en veninde, da vi tænkte at det kunne være sjovt og mindeværdigt. Men da vi kom ind i chatrummet, fik vi det største chok. Børnene kaldt hinanden dumme og grimme, og var bare rigtig onde over for hinanden. Det er chokerende at den digitale mobbe alder ligger på 9 år. 


\section{S. Troelsen}

Uni-Login: $\mathrm{xxx}$

Klasse: 9.

Dansk skriftlig fremstilling, opgave nr. 1 Digital mobning.
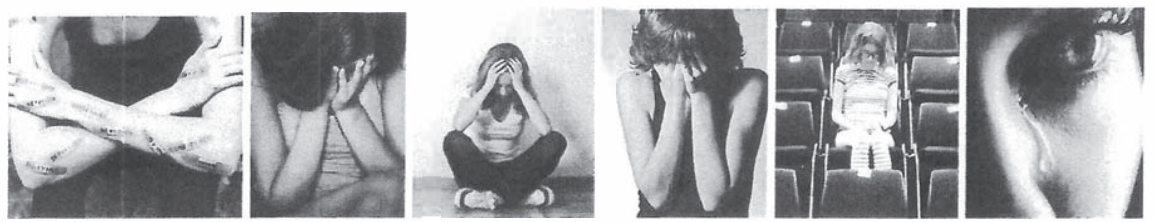

Jeg har også selv prøvet at være offer for digital mobning og jeg har fået private billeder sendt ud. Der opstår en voldsom ubehagelig følelse i kroppen når beskederne ruller ind, maven gør ondt, og der opstår en følelse af tomhed. Tankerne begynder at kører rundt og er virkelig på arbejde. Da jeg havde oplevede det nogle gange, gjorde det faktisk at jeg fik tanker om hvordan verdenen ville se ud uden mig. Jeg havde følelsen af, at når jeg gjorde skade på mig selv, så var det en befrielse. Jeg kunne mærke mig selv og det var tilfredsstillelse. Men det gjorde også at jo flere gentagelser der var, jo mere druknede jeg i det sorte hul jeg havde skabt. Jeg fik heldigvis hjælp på ungecenteret i Aarhus, og er nu på vej op igen. Men det har faktisk ført til at jeg i dag er meget lukket ind i mig selv, jeg vil helst være alene, jeg har svært ved at åbne mig og være mig selv overfor nye mennesker og jeg går meget rundt i min egen verden.

For at forebygge at børn og unge bliver slugt af alle de beskeder og ydmygelser, synes jeg der skal tages meget fat i det i skolen og undervisningen. Der skal vises nogle flere film og dokumentarer om mobning, så mobberne får et indblik i hvordan drillerierne påvirker ofrene. Der skal være flere samtaler mellem lærer og elev, specielt i de større klasser, da det er i teenageårene unge er mest udsatte. 


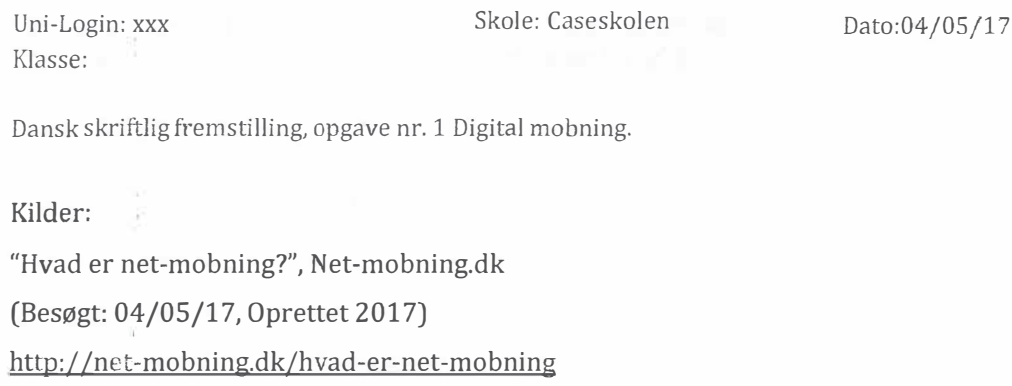




\section{S. Troelsen}

\section{Bilag 5: Marikas tekst}

Unilogin: $\mathrm{xxx}$

Caseskolen, 9
Dansk skriftlig fremstilling

Opgave: 4, Humor
04-05-2017

\section{Danskerne er vilde med ironi}

Humoren er, en stor del af danskernes hverdag, både på jobbet og i hjemmet. Men den såkaldte ironi er ikke altid til at forstå for alle, især hvis man ikke er vokset om med ironien som en naturlig ting.

\section{Vi er vilde med humor}

Vi danskere er efterhånden blevet ret vilde med en god joke. Det er med tiden blevet umuligt, at træde udenfor sin egen hoveddør, før den danske humor rammer os med stormstyrke. I reklamerne, i skolen og på arbejdspladsen. Ja selv i avisen er der tegneseriestriber, der faktisk vil gøre alt, for at få netop DIG til at smile. Måske endda få dig til, at dreje kontorstolen 180 grader, og grine en ekstra gang, nu med kollegaen. Og hvis kollegaen er rigtig heldig, får han lov til, at klippe den ud, og hænge den op på køleskabet derhjemme.

\section{Hvornår er det sjovt?}

Og hvornår går det over stregen? Ironi er en stor del af den danske humor. Som integreret dansker vil man finde det naturligt med lidt ironi i hverdagen. Men ser man på den danske humor - og ironi, udefra er det med et fuldkomment andet syn. Danskerne misforstås nemt på international basis, der er humoren anderledes, men det er sproget også. Tonen i

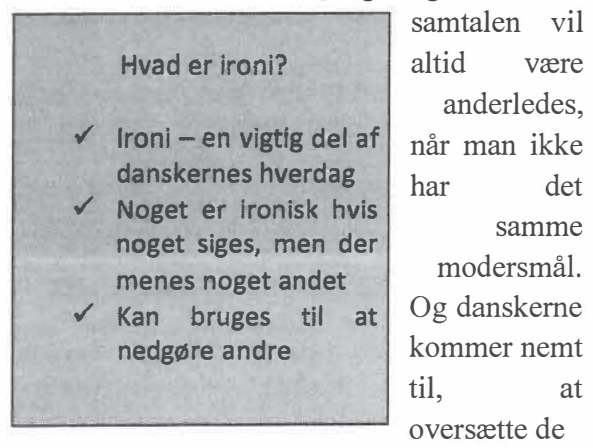

danske ord og vendinger, en smule for direkte. Så ofte vil en amerikansk mand slet ikke forstå sammenhængen, og vil derfor hurtigt tolke situationen forkert.

Udover det, er dansk kendt for, at være et svært sprog. Og vi gør det bestemt ikke nemmere for nogen, når vi også bruger ironien over får folk vi har mødt i netop samme øjeblik.

I Danmark er det normalt, at have en snak med konkurrenten. Og det er normalt, at gøre lidt grin med den muglige kommende situation, hvor der ikke vil være tid til hyggesnak. Det er sådan kulturen er, og der skiller vi os bestem't ud, selv inde for rimelige verdens grænser.

\section{Griner vi af eller med hinanden?}

Udover, at man skal kunne forstå meningen $\mathrm{i}$ ironien, skal man også kunne forstå når den bliver brugt mod en. Her sammenligner Mette Møller der er forsker i retorik, os med latinamerikanerne. "Det har meget at gøre med, at vi driller meget, vi stikker til hinanden. I Latinamerika er man gode til at kalde hinanden navne. Det er lidt den der uhøjtidelighed, vi tager det ikke så tungt."

Hvis man ikke kan tage en joke eller lidt ironi, bliver man nemt stemplet som hende den kedelige. Det at have en humoristisk sans bliver en vigtigere og større værdi, og det bliver i den grad hvert sat.

\section{Store problemer bliver til små}

Danskerne er også blevet rigtig gode til, at bruge humor og ironi omkring de problemer man nu kan have. Hovedsagligt hvis man snakker om noget der rører en meget, og det pludselig kommer lidt for tæt på. Der er 
danskerne gode til at fortælle en lille joke, så det bliver knap så seriøst. Og efter det virker problemet heller ikke så slemt, som det gjorde til at starte med.

Det samme gælder hvis der skal bringes en dårlig nyhed eller siges nok negativt.

Igen vælger man at gå til ironien, problemet virker mindre og selvtilliden større.

Af [har skrevet sit unilogin] 
S. Troelsen

Unilogin: $x x x$

Dansk skriftlig fremstilling

04-05-2017

Caseskolen, 9 Kildeliste

\section{Kildeliste}

- Tv2 Lorry, Hvad er dansk humor, tv2lorry.dk, http://www.tv2lorry.dk/lounge/hvad-erdansk-humor, 04-05-2017

- Morten Rasmussen, Ironi er ikke noget problem, Kristeligt dagblad, https://www.kristeligtdagblad.dk_danmark/ironi-er-ikke-noget-problem , 04-05-2017 


\section{Bilag 6: Veronicas tekst}

Unilogin $\mathrm{xxx}$

04-05-2017
Dansk skriftlig fremstilling

Opgave nr. 3
Caseskolen 9.

Hvorfor må vi ikke kalde vores børn for "prinsesser"?

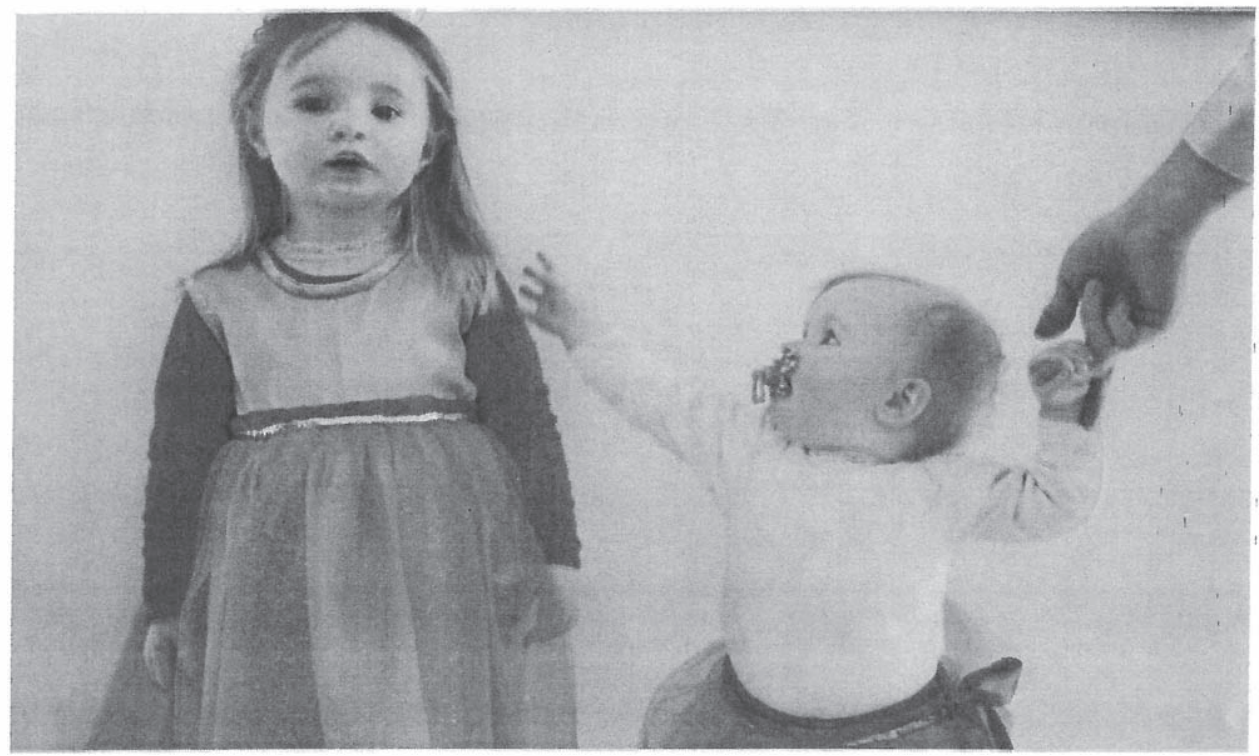

Små prinsesser ser op til større prinsesser

Af [har skrevet sit unilogin her]

Michael Robaks syn på små "prinsesser" synes jeg er meget generaliserende, bla. skriver han at alle eventyrprinsesser, som vores døtre ser op til, har lyserøde balkjoler og fine glassko på. Sådan var det måske for 10 år siden, men siden da er prinsesser som Pochahontas og Mulan altså kommet til, begge kæmper for retfærdighed, og de har i hvert fald ikke lyserøde balkjoler på, imens de gør det.

Han slår også ned på at det er blevet meget populært, især blandt mødre at oprette en konto, på de sociale medier, hvor de poster billeder af deres børn. En af mine bekendte har en profil, hvor hun poster billeder af sine to døtre. Jeg er sikker på at børnene synes at det er vældig sjovt at lege og klæde sig ud som prinsesser, mens mor tager et billede, og bagefter smider det på Instagram eller Facebook.

Man ser tit forældre tage billeder af deres børn. Om det så bliver lagt ud på de sociale medier er børnene jo ligeglad med, de ser jo ikke hvor mange likes eller dislikes de får, og det er de da også ligeglade med. Børnene vil bare gerne have det sjovt. 


\section{S. Troelsen}

Unilogin 3

04-05-2017
Dansk skriftlig fremstilling

Opgave nr. 3

Caseskolen 9.

I denne her sammenhængen er de sociale medier til for forældrene, og ikke for børnene, og har derfor heller ikke nogen effekt på dem.

Så kan det godt være at nogle mennesker, ikke gider at se billeder af andre forældres "prinsesser", men så må de jo lade vær med at kigge, og scrolle videre.

Hvis nogle forældre gerne vil kalde deres døtre for prinsesser, så lad dem da. Vi andre kan da være ligeglade, og det er jo heller ikke os der skal bestemme om de vil kalde deres barn for en prinsesse eller ej.

Jeg synes godt at vi kan tillade os at kalde vores døtre for prinsesser, der er ikke noget i vejen med at give dem et selvtillids-boost med på vejen. Jeg tror faktisk at det hjælper børnene med at tro på sig selv, fordi de som oftest ser op til prinsesser, og derfor gerne vil være ligesom dem.

På den anden side kan det få børnene til at tro at de SKAL være ligesom prinsesserne i Disney-filmene. Eller få dem til at tro at de er hævet over alle andre, og derfor ikke skal lave noget, men kan nøjes med at sidde på deres flade røv. Dette kan føre til problemer på deres fremtidige arbejdsplads, eller gøre det svært for dem overhovedet at finde et job, fordi de ikke har en god arbejdsmoral.

Jeg mener dog sagtens at man kan kalde sin datter for en prinsesse, uden at der følger nogle grimme konsekvenser i fremtiden. Det handler om opdragelse. Om at lærer sit barn at tro på sig selv og sætte sig mål. Lære dem at man skal "yde for at nyde", og at alt ikke bare kommer flyvende til dem.

Der var jo ingen der sagde at det var nemt at være en prinsesse.

Kilder:

Friss, Ann-Katrine, "Mumma: To små prinsesser + DIY", www.mumma.dk 4. Maj 2017, http:L/www.mumma.dk/2014/03/to-sma-prinsesser-diy.html

Skotte, Kim, "Film er det muhliges kunst", www.aiu.dk, 4. Maj 2017, http://aiu.dk/mediehandbogen/wp-content/uploads/2013/06/Kommentar-1Politiken.pdf 


\section{Bilag 7: Emmas tekst}

$x X x$

CASESKOLEN
SKRIFTLIG FREMSTILLING

OPG. 1 DIGITAL MOBNING
4/5-2017

'ESSAY

\section{Teknologiens skyggeside}

Et essay skrevet af Emma Xxxx Xxxxx

Jeg ser det dagligt. Andre bliver hængt ud på nettet, men jeg gør ikke noget. Andre bliver svinet til på billeder eller opdateringer, men jeg gør ikke noget. Andre får nedladende kommentarer eller beskeder tilsendt på deres sociale medier, men jeg gør stadig ikke noget.

Det sker hver dag i hele verden. Flere hundredtusinder unge er nærmest blevet "vant" til det. En besked tikker ind, sådan forsætter det, og kort efter er der 22 ulæste beskeder. Beskeder som er fyldt med negativitet, had og ikke mindst er i gang med, at dræbe selvtilliden hos andre. Beskederne er ligesom en tikkende bombe, som man aldrig ved, hvornår sprænger. Afsenderen er ikke klar over, hvad han/hun er ved at gøre. Afsenderen gør det egentlig blot for at komme ud med noget had, få noget status hos vennerne, og vise at det er ham/hende som har magten. Modtageren sidder derefter tilbage med kolde og fortabte følelser. Følelser af at der er ingen, som kan lide én. Følelser af at man er helt alene, og at alt er ens egen skyld.

Kan det virkelig være rigtigt, at unge mennesker skal bruge deres mobiler på den måde? Hvor er forældrene henne? Er verden virkelig blevet så kold og kynisk? Hvor meget skal der til før, at folk griber ind? Vi har kendt mobning i så mange år, men hvorfor bliver det nu så voldsomt?

Mit bedste svar på disse spørgsmål vil nok være, at tiderne ændre sig. Det samme gør teknologien og sproget. I dag har vi noget af det bedste it-udstyr i verden, og stort set alle render rundt med dyre iPhones, Smartphones og andre moderniserede telefoner. De fleste unge kan sikkert relatere til, at hele ens liv er på de firkantende, bippende, små dimser. Man kan bruge de sociale medier og mobiler til så mange fantastiske ting, men der vil også følge de mere negative sider med. I dette tilfælde er det digital mobning. Det kræver så meget mere, af en person at skulle opsøge en anden', og derefter begynde at latterliggøre personens udseende eller værdier. Derfor tror jeg, at det er til dels mere udpræget, at mobbe på nettet i stedet for at sige det ansigt til ansigt. Det er så meget lettere lige, at skrive nedladende ord om andre og derefter trykke send, end at skulle sige det direkte til én. Faktisk tror jeg det er så meget hårdere, at modtage en besked fyldt med had, end at få det sagt til én. Det med at man ikke kan se ansigtsudtrykket på afsenderen forstærker virkelig nederlaget.

Sproget i dag synes jeg virkelig også er hårdt. Jeg føler ikke nogle unge kan fuldføre en sætning, uden at udfylde den med flere forskellige bandeord. I Danmark er vi efterhånden blevet så gode til engelsk, at vi har taget en del engel $r$ ske ord til os. Til dels er det positivt, men til dels også negativt. For deriblandt er der kommet en del bandeord, men også en lang række nedladende ord til. Efterhånden synes jeg vi danskere er blevet for "gode" til at tage det engelske sprog i brug. Der er en del, som bruger det engelske sprog til at række ned på andre, og det synes jeg er helt forkert. I dag har man på en måde to sprog, som man kan svine folk til på, hvor før i tiden var det kun dansk, så man kan sige, at udvalget er blevet større, og det er helt forkert. 


\section{S. Troelsen}

$\mathrm{XXX}$

Set i bakspejlet kan jeg godt se, at jeg skulle have grebet ind, den første gang jeg så de negative opslag poppe op på min Facebook-side. Sandheden er, at jeg tror ikke ville kunne bære, hvis jeg pludselig selv fik noget modstand. Derimod, hvis flere og flere begynder at sige fra overfor at mobberne, så tror jeg det ville være meget lettere. Men hvem tør bryde den onde cirkel? Hvem tør tage ansvar og gøre det eneste moralske rigtige. Når man først enten har mobbet eller har observeret mobning, er det svært at bryde ud igen. Man ved jo ikke, om man er den næste der står på spil, når man går imod strømmen. Det er som om mobningen blot bliver værre og værre. Mange tror at mobning, blot skader den person, som bliver udsat for de onde beskeder osv., men sandheden er, at alle som bare er i berøring med mobningen bliver skadet. Hele samfundet tager skade af mobning, for der vil i alles hjerter være efterladt et spor af psykisk angst. En angst for måske at være den næste, som bliver mobbet. Selvfølgelig er det af forskellige grader, men inderst inde vil der altid være spor af mobning.
På min skole synes jeg, at vi har brugt en del timer på at snakke om mobning. Vi har haft flere kampagner om emnet, og jeg føler ikke længere det er et tabu at tage op. For at få sat en stopper for mobning, tror jeg man skal sætte endnu mere fokus på det og lave endnu flere kampagner, end man gør i dag. På den måde tror jeg flere bliver opmærkesomme, når de støder på mobning og kan hjælpe hinanden med at få det stoppet.

I stedet for at bruge en masse tid på det negative, så synes jeg, at man skal fokusere på det positive i livet. Være taknemlig for alle de gode mennesker, som man er omringet af til hverdag, værdsætte forskellighederne og vise taknemlighed for tilværelsen.

Med disse ord skrevet vil jeg gribe ind i kampen mod digital mobning. Næste gange jeg. ser ondskabsfulde, groteske og ydmygende kommentarer på de sociale medier, vil jeg sige fra. Bakke ofrene op og mobberne ned. 


\section{At håndtere flertydighed under pres}

$\mathrm{XXX}$

CASESKOLEN
SKRIFTLIG FREMSTILLING

OPG. 1 DIGITAL MOBNING
4/5-2017

ESSAY

Kildeangivelse:

Genreplakaten essay, Iskriv.dk, 4/5-2017,

http://www.iskriv.dk/Data/Courses/144/Essay\%201_Genreplakat.pdf 


\title{
S. Troelsen
}

\section{Bilag 8: Samiras tekst}

Caseskolen

D.S.F
751033

9. kl. unilogin $\mathrm{xxx}$

Dato: 04.05.17

\section{Mobning på digital plan}

\author{
Af Samira Xxxxxxx
}

Nu er det nok. Internet mobning har ramt Danmark, og vi er alle med i faldet. Når nogle vågner op fra en dejlig drøm, ser de frem til hvad hverdagens kolde brise bringer. Og andre smækker øjnene tungt i igen, for at drømme sig lang væk fra deres brutale hverdag, der atter banker på døren. Når nogen får en besked, samler de ubekymret straks deres telefon op, imens andre ikke engang tør røre telefonen. Jeg har undret mig over hvordan det må være, at opleve mobning.

Jeg vil ikke i skole. Hver eneste dag er ens. Så snart jeg sætter dig ned på den kolde splint fyldte træstol, kan jeg mærke de kolde dømmende blikke i nakken af mig, de hæslige kommentarer høre jeg gentagne gange, som en hvisken fra hvert eneste kolde hjørne i klasselokalet. "Har du set hendes nye profilbillede, hun er bare en fed luder."

Og efter at jeg har hørt det samme gentagne gange, så begynder du at tro på det. Min krop er min egen fjende. Den er jo grunden til at jeg bliver mobbet. Det er min egen skyld. jeg fortjener ikke en skid, for jeg er jo nytteløs. Jeg skal dø!

Det havde jeg aldrig tænkt på før. Fortjener jeg nu ikke at leve?

Det gøre så ondt at få nedladende kommentarer fra andre, at man begynder at skade dig selv. Det starter med en stram elastik på håndledet, som jeg trækker i, hver gang jeg bliver deprimeret. Min depression påvirker min skolegang, så mine forældre snakker med mig. Jeg siger ikke noget, for de vil ikke forstå. Jeg bliver tvunget til at flytter skole. Folk har allerede set hvad der stod på mit billedet, så jeg bliver også mobbet på den skole. Hvad har jeg gjort?

Hvad er årsagen til mobning? Hvordan og hvornår stopper det?

De fleste siger at mobberen selv gennemgår angst problemer, men er det så okay at mobbe? Jeg er aldrig blevet udsat for mobning, men jeg har set det spire hurtigere end klematis. De røvrente psykologer siger, det er en angstmekanisme. Men hvad gøre man for at stoppe det. Det påvirker alle, tanken om at en gennemgår det lige nu, dræner min hjerne for positivitet. Jeg har set det ske, men havde aldrig nosser nok til at bekæmpe det.

Jeg har altid troet, at grunden til at man fik en nedladende kommentar, var fordi at personen var jaloux. Men er det dybere end det?

Vi kan hurtigt sige, at et grufuldt antal børn og unge gennemgår mobning. Men vi kan ikke hurtigt komme med en luftig forklaring på hvorfor. Undersøgelserne online har virkeligt sat mine tanker i gang. For selvom vi lever i et fornuftigt samfund, så er der stadig mange problemer som disse, der bliver skubbet til side. Det rammer og svækker vores samfund. Mobbere mobber fordi at de har det forfærdeligt med sig selv. Og når de mobber, så er det deres måde at råbe efter hjælp på. 
Tænk over det, ville en person som har det $100 \%$ godt, få andre til at føle sig dårligt. Det er det som jeg har fundet frem til. Og i stedet for at holde sig tilbage så burde man konfrontere dem før det går galt, med en voksen eller ven. Man kunne starte ud med at sige: "Er der en grund til at du vil have at jeg skal hade mig selv, udover at jeg er klam, dum og grim?" Du vil blive overrasket over svaret. Jeg har selv prøvet at konfrontere en person som plejer at kalde mig øgenavne. Og selvom det ikke var en intens situation, så fik jeg stadig et overraskende svar.

Alle folkeskoler skulle gerne være, et trygt sted for unge at være. For det er der de bruger cirka $20 \%$ af deres barndom. Hvis man så er bare en lille smule anderledes fra de andre børn, bliver man så mobbet?

Vi burde have klassens time, hvor man kunne bygge på et tættere fællesskab. Internet regler, som ville sætte grænser for retarderet unge. Og mennesker som tager initiativ i situationer som disse. Vi danskere er et stort frimodigt samfund, så derfor er det vigtigt at holde styr på hinanden.

Man burde få fortalt som barn at være speciel er godt, så man senere hen ikke dømmer eller bliver dømt på ens ydre. Og det er for dårligt at folk ikke kan forstå betydningen med citatet: "Det du giver, får du tilbage." Vi skal alle have chancen for at vågne med et smil på læben, en dejlig sommermorgen, med en sød klang af fuglenes fløjten og begejstringen af den positive hverdag som venter.... Synes du ikke det? 


\section{S. Troelsen}

\section{Bilag 9: Astas tekst}

Caseskolen

$\operatorname{xxx}$
Dansk skriftlig fremstilling

Digital mobning
4. Maj 2017

9.D

\section{Tænk dig om en ekstra gang}

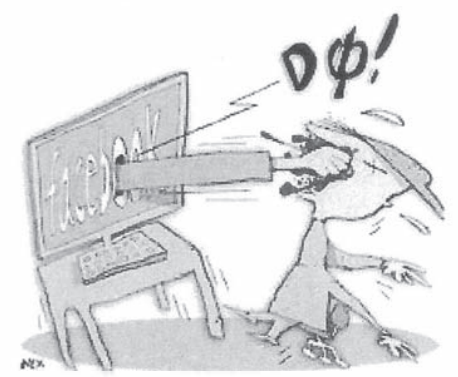

Kilde: Poliwiken

"Du er det klammeste klamme. Du tror, du er lakker. Du er led, dum og en smatter." Beskeder som disse modtager mange unge hver dag, og jeg synes, det er helt sindssygt. En ting er dog at modtage dem, en anden ting er at skrive dem. "Du vil do alene $i$ verden, og vi vil skide på din gravkiste." Hvem kan få sig selv til at skrive det til et andet menneske?

Det er dog en anden ting, når det foregår over nettet eller sms. Det er som om, man føler, man kan tillade sig mere. Det er også lettere at gemme sig bag en skærm end at skulle sige så forfærdelige ting til en persons ansigt. Men hvordan starter mobningen?

Jeg har tidligere været del af en gruppe på Facebook der hedder Offensimentum. Det er en gruppe, de fleste unge omkring 9. klasse er med i, og hvis du ikke er med i den, har du nok hørt om den. Den var lavet som et samlingssted for unge, men den går dybest set ud på at svine andre til. Jeg var til sidst nødt til at melde mig ud af den, for det var for uudholdeligt at være en del af. I starten forstod jeg ikke, hvorfor de gjorde det. Hvorfor der var sådan en trang til at skrive lede ting om hinanden. En pige ville poste et billede af sig selv, og alle drenge ville skrive ting som "kran" eller "grimme cancer so". Senere kunne jeg godt se, at man kunne blive populær, hvis man skrev noget, der var ekstra opfindsomt eller ekstra nederen. Jeg fandt lige et facebookopslag i gruppen, som der kom meget debat om. Et lille uddrag lyder: 'Til vores alles dejlige ___. Synes bare bun skulle banges op, imens der er en, der smider global knive efter hende, $i$ häb om at hendes mave spratter op, og hendes organer ryger ud og bliver fodret til hundene." Tanken om at en person rent fakisk har siddet og skrevet det, gør mig helt dårlig. Uanset hvad hende pigen har gjort, vil det der ALDRIG være okay at skrive. Det her var også et af de værste opslag, jeg har set længe, alle er heller ikke så slemme. Nogle er faktisk også bare ment for sjov, men de ender alligevel med ikke at være sjove.

Jeg kan huske engang, min ven for sjov lagde en video op af to af sine venner. Han skrev "rate dem fra 1-10". Det startede som en joke, men det blev hurtigt groft, og pludselig var det ikke sjovt mere. Jeg tror, det er tilfældet med mange af opslagene. Det starter ud som noget for sjov, men det ender med, at nogle bliver kede af det.

Generelt tror jeg også, det er farligere at være grove på nettet, fordi man kan misforstå hinanden på flere forskellige måder, og man kan ende med at gøre nogen mere kede af det, end det egentlig var meningen. 
Man kan for eksempel ikke høre i tonefaldet, om afsenderen er sarkastisk eller dybt alvorlig, og afsenderen kan ikke se ansigtsudtrykket eller reaktionen på modtageren og ved ikke, om hun eller han er mere ked af det, end man skulle tro.

Jeg tror også for det meste, at folk tager beskeder mere alvorlige og personlige, end de var ment. Jeg kan også huske engang, da vi ikke var så gamle, og en af mine veninder havde fødselsdag. Fordi jeg var ked af, at hun ikke kunne komme til håndboldtræning den dag, skrev jeg et opslag på hendes væg: 'Fuck det er nederen, at du ikke kommer til traning $i$ dag din prut!' Eller noget i den stil, og hun havde taget det meget mere personligt, end jeg troede. Hun blev faktisk ked af det over min besked, og jeg måtte skynde mig at sige, at det altså bare var for sjov, og at det bare var fordi, at jeg ville savne hende til træning.

Det er dog ikke en undskyldning for at skrive lede beskeder. Jeg tror uanset hvad, skal man altid tænke over det en ekstra gang, inden man sender en besked, der måske kan misforstås eller gøre nogen kede af det, for er det virkelig det værd? At ødelægge nogens dag? Jeg synes ikke, der er nogen, der fortjener beskeder som "Spring ud foran et tog. Vi gider dig ikke mere".

Men hvad kan man gøre ved det? Jeg tror, det bliver helt vildt svært at stoppe internemobning. Vi kan selvfølgelig alle sammen tænke en ekstra gang, inden vi sender en besked, og det kan sagtens være, det hjælper en del, men der vil altid være grupper som Offensimentum, og jeg ved ikke, om de er svære at få nedlagt. Der vil desværre sandsynligvis altid være mennesker, som ikke tænker sig om og glemmer at tænke på hvor meget en besked kan påvirke andre, men jeg håber, at de en dag opdager det. 


\section{S. Troelsen}

\section{Bilag 10: Esters tekst}

Skole: Caseskolen

Klasse: 9

Skriftlig fremstilling, opgave 1 - Digital mobning

Uni·login: $\mathrm{xxx}$

\section{Søndagsstuen}

Jeg krammede min vinterjakke tæt ind til mig og spejdede ud over fritidshjemmets tomme gang. De hullede, råhvide vægge var dækket af håndmalede, glade ansigter, som formodentlig havde til formål at give de unge på stedet et smil på læben. Bag døren til fællesrummet, hørte jeg stemmer, som ihærdigt snakkede og overdøvede hinanden. Med korte skridt, begav jeg mig lydløst hen over det rødbrune, støvede flisegulv. Fra den ene dag til den anden var fritidshjemmet pludselig et ubehageligt sted at være. Jeg satte mig ind på et af toiletterne, tog min telefon op af lommen og klikkede mig ind på den besked, jeg modtog i går aftes. "DU SKAL DØ, DIN FUCKING SKØGE” stod der. Jeg mærkede et sug i maven.

Virksomheder udnytter dem, de ældre afskyr dem og de unge er en generation af digitale indfødte på grund af dem. "Dem" er de sociale medier, og i nutidens samfund er vi tvunget til dagligt at bruge flere timer på digitale platforme for at indgå i fællesskabet, selvom vi sandsynligvis sagtens kunne været været den virtuelle verden foruden. En stor del af vores hverdag foregår online, og selvfølgelig understøtter de sociale medier dialog såvel som fællesskab, men der er dog også visse ulemper ved trenden. En af dem er digital mobning. De grove beskeder er ofte meget hårdere i sproget end de ord, vi ville bruge i en samtale ansigt til ansigt, ville være, men er det os alle, der er klar over det?

Nu går jeg i niende klasse og siden dødstruslen i femte klasse, har jeg været meget opmærksom på min egen opførsel. Jeg er stadig ikke klar over hvilken af mine handlinger, der har fået nogen til at sende mig en så brutal besked. I dag, da jeg havde spisefrikvarter, sad jeg alene ved mit bord i klassen med min madpakke. I modsatte hjørne af lokalet sad to piger og snakkede om en Facebook samtale, en af dem havde kørende med en dreng fra parallelklassen. Som en flue på væggen smuglyttede jeg diskret, men da ord som homo, luder og bitch blev læst op, fik jeg en krumme fra min rugbrødsmad galt i halsen. Jeg hostede, som var jeg rent faktisk 
nær døden, og blev opdaget i at lytte med. Pigerne sendte mig hånende blikke og blev med øjnene enige om at fortsætte snakken ude på gangen.

Nu hvor jeg er blevet ældre, tænker jeg tit på, om den, der i femte klasse sendte mig en hadebesked, var klar over, hvad det var, han eller hun havde sendt afsted. Var personen klar over, at jeg sad i modtagerenden, og rent faktisk overvejede tanken om at tage afsked med livet? Det tror jeg ikke. Hvad det er i os, der tager nogle ting tungere end andre, ved jeg ikke. Jeg ved dog af erfaring at de misforståelser, der kan opstå, når vi interagerer over internettet, har stor indvirkning på vores humør, og at de voksne kan have særligt svært ved at forstå det. Er det den digitale verden, der er skyld i, at vores forældre ikke længere er underrettede om, hvordan vi har det?

Mobning er gennem de seneste år flyttet fra skolegården til de sociale medier, og jeg tror, at en hadebesked fra en anonym forfatter gør mere ondt end en omgang buksevand. Den mulighed internettet giver os for at være anonyme, tolker nogen muligvis som frit slag til at svine andre mennesker til. De sociale medier burde efter min og sikkert også mange andres mening ikke gøre os overmodige og få os til at glemme, hvordan vi skal kommunikere med vores medmennesker. Med de mange muligheder der er for at se, høre og læse om store såvel som små katastrofer, bør internettet tværtimod gøre os klogere på vores handlinger og konsekvenserne af dem.

Om søndagen er min telefon gemt langt væk mellem sofapuderne, og det eneste, der optager mig, er lyden af jazz, der spiller ud gennem højtalerne i den anden ende af stuen. Solens stråler varmer mit ansigt, og jeg smiler og kigger ned på børnene, der leger med hinanden i gården. En af dem snubler og falder, og den anden hjælper ham op. Jeg sidder i min vindueskarm med en varm kop te, og håber på, at det spædbarn, jeg forhåbentligt en dag i fremtiden sidder med i armene, kan vokse op i et samfund, hvor man passer på og tager hensyn til hinanden. Ikke kun i den virkelige verden, men også i den virtuelle. Et samfund hvor der er plads til at alle kan være mennesker, for det er jo det, vi er. Er det ikke? 


\section{S. Troelsen}

Skole: Caseskolen

Klasse: 9

$4 \cdot 5 \cdot 2017$

Skriftlig fremstilling, opgave 1 - Digital mobning

Uni.login: 5

\section{Kildeangivelser:}

- Politiken, Derfor har de det svært: Tag et kig ind i de unges digitale hverdag politiken.dk

http://politiken.dk/forbrugogliv/livsstil/trivsel/art5543949/Derfor-har-de-det-sv\%

C3\%A6rt-Tag-et-kig-ind-i-de-unges-digitale-hverdag 3. maj 2017

- Hvad er net-mobning - netmobning.dk,

http://net-mobning.dk/hvad-er-net-mobning, 3. maj 2017 


\section{Bilag 11: Ortografiske fejltyper i de fire eksempeltekster}

\begin{tabular}{|l|l|l|l|l|}
\hline \multicolumn{2}{|c|}{ Anna } \\
\hline Semantiske fejl & $\begin{array}{l}\text { Morfologiske fejl (fx } \\
\text { bøjningsfejl) }\end{array}$ & $\begin{array}{l}\text { Idiomer/ } \\
\text { ordforbindelser }\end{array}$ & Særskrivningsfejl & $\begin{array}{l}\text { Korrekturfejl/ } \\
\text { slåfejl }\end{array}$ \\
\hline forsager (forårsager) & $\begin{array}{l}\text { mærkelige } \\
\text { (mærkelig) }\end{array}$ & $\begin{array}{l}\text { i færgen (på } \\
\text { færgen) }\end{array}$ & sand banke (sandbanke) & med (men) \\
\hline foreløbelig (foreløbig) & passered (passeret) & $\begin{array}{l}\text { vi takker i (vi } \\
\text { takker) }\end{array}$ & $\begin{array}{l}\text { tids udtrækning } \\
\text { (tidsudtrækning) }\end{array}$ & $\begin{array}{l}\text { der hjemme } \\
\text { (derhjemme) }\end{array}$ \\
\hline forsaget (forårsaget) & mandelig (mandlig) & & ægte par (ægtepar) & \\
\hline i (I) & forsigtig (forsigtigt) & & der efter (derefter) & \\
\hline $\begin{array}{l}\text { varder os ... op (varter os } \\
\text { op) }\end{array}$ & forståligt (forståeligt) & & & \\
\hline indberetning (beretning?) & & & & \\
\hline snaksaglige (snakkesalige) & & & & \\
\hline sku (sgu) & & & & \\
\hline
\end{tabular}

\begin{tabular}{|l|l|l|l|l|}
\hline \multicolumn{5}{|c|}{ Emre } \\
\hline Semantiske fejl & $\begin{array}{l}\text { Morfologiske fejl (fx } \\
\text { bøjningsfejl) }\end{array}$ & $\begin{array}{l}\text { Idiomer/ } \\
\text { ordforbindelser }\end{array}$ & Særskrivningsfejl & $\begin{array}{l}\text { Korrekturfejl/ } \\
\text { slåfejl }\end{array}$ \\
\hline hans (sin) x 3 & gøre (gør) x 2 & $\begin{array}{l}\text { må ikke med (må } \\
\text { ikke komme med) }\end{array}$ & $\begin{array}{l}\text { personale døren } \\
\text { (personaledøren) }\end{array}$ & lige (lide) \\
\hline ligger (lægger) & passagerne (passagererne) & vi alle griner & $\begin{array}{l}\text { fem og halvfjerds } \\
\text { (femoghalvfjerds) }\end{array}$ & \\
\hline i (I) & distrahere (distraherer) & vi alle begynder & tysk stilen & \\
\hline Karen & glad (glade) & $\begin{array}{l}\text { spilder tiden } \\
\text { (fordriver tiden) }\end{array}$ & & \\
\hline $\begin{array}{l}\text { drengerøve } \\
\text { (drengestreger) }\end{array}$ & stirre (stirrer) & & & \\
\hline & massere (masser) & & & \\
\hline
\end{tabular}

\begin{tabular}{|l|l|l|l|l|}
\hline \multicolumn{5}{|c|}{ Ester } \\
\hline Semantiske fejl & $\begin{array}{l}\text { Morfologiske fejl (fx } \\
\text { bøjningsfejl) }\end{array}$ & $\begin{array}{l}\text { Idiomer/ } \\
\text { ordforbindelser }\end{array}$ & Særskrivningsfejl & $\begin{array}{l}\text { Korrekturfejl/ } \\
\text { slåfejl }\end{array}$ \\
\hline nogen (nogle) & & $\begin{array}{l}\text { Facebook samtale } \\
\text { (Facebook-samtale) }\end{array}$ & $\begin{array}{l}\text { været været (have } \\
\text { været) }\end{array}$ \\
\hline
\end{tabular}

\begin{tabular}{|l|l|l|l|l|}
\hline \multicolumn{2}{|c|}{ Marika } & Særskrivningsfejl & $\begin{array}{l}\text { Korrekturfejl/ } \\
\text { slåfejl }\end{array}$ \\
\hline Semantiske fejl & $\begin{array}{l}\text { Morfologiske fejl } \\
\text { (fx bøjningsfejl) }\end{array}$ & $\begin{array}{l}\text { Idiomer/ } \\
\text { ordforbindelser }\end{array}$ & $\begin{array}{l}\text { om } \\
\text { ( ) }\end{array}$ \\
\hline muglige (mulige) & $\begin{array}{l}\text { fuldkomment } \\
\text { (fuldkommen - } \\
\text { adv.) }\end{array}$ & & $\begin{array}{l}\text { inde for rimelige verdens } \\
\text { grænser } \\
\text { (inden for rimelighedens } \\
\text { grænser) }\end{array}$ & $\begin{array}{l}\text { nok } \\
\text { (noget) }\end{array}$ \\
\hline inde for (inden for) & & & & \\
\hline $\begin{array}{l}\text { hvert sat (værdsat) } \\
\text { (hovedsagligt }\end{array}$ & & & & \\
\hline
\end{tabular}

